NUREG/CR-2893 PNL-4395

\title{
Correlation of Neutron Data Taken at Commercial Nuclear Sites
}

Prepared by L. A. Rathbun, G. W. R. Endres

Pacific Northwest Laboratory

Operated by

Battelle Memorial Institute

Prepared for

U.S. Nuclear Regulatory

Commission 


\section{NOTICE}

This report was prepared as an account of work sponsored by an agency of the United States Government. Neither the United States Government nor any agency thereof, or any of their employees, makes any warranty, expressed or implied, or assumes any legal liability of responsibility for any third party's use, or the results of such use, of any information, apparatus, product or process disclosed in this report, or represents that its use by such third party would not infringe privately owned rights.

\section{Availability of Reference Materials Cited in NRC Publications}

Most documents cited in NRC publications will be available from one of the following sources:

1. The NRC Public Document Room, 1717 H Street, N.W. Washington, DC 20555

2. The NRC/GPO Sales Program, U.S. Nuclear Regulatory Commission, Washington, DC 20555

3. The National Technical Information Service, Springfield, VA 22161

Although the listing that follows represents the majority of documents cited in NRC publications, it is not intended to be exhaustive.

Referenced documents available for inspection and copying for a fee from the NRC Public Document Room include NRC correspondence and ir.ternal NRC memoranda; NRC Office of Inspection and Enforcement bulletins, circulars, information notices, inspection and investigation notices; Licensee Event Reports; vendor reports and correspondence; Commission papers; and applicant and licensee documents and correspondence.

The following documents in the NUREG series are available for purchase from the NRC/GPO Sales Program: formal NRC staff and contractor reports, NRC-sponsored conference proceedings, and NRC booklets and brochures. Also available are Regulatory Guides, NRC regulations in the Code of Federal Regulations, and Nuclear Regulatory Commission /ssuances.

Documents available from the National Technical Information Service include NUREG series reports and technical reports prepared by other federal agencies and reports prepared by the Atomic Energy Commission, forerunner agency to the Nuclear Regulatory Commission.

Documents available from public and special technical libraries include all open literature items, such as books, journal and periodical articles, and transactions. Federal Register notices, federal and state legislation, and congressional reports can usually be obtained from these libraries.

Documents such as theses, dissertations, foreign reports and translations, and non-NRC conference proceedings are available for purchase trom the organization sponsoring the publication cited.

Single copies of NRC draft reports are available free upon written request to the Division of Technical Information and Document Control, U.S. Nuclear Regulatory Commission, Washington, DC 20555.

Copies of industry codes and standards used in a substantive manner in the NRC regulatory process are maintained at the NRC Library, 7920 Norfolk Avenue, Bethesda, Maryland, and are available there for reference use by the public. Codes and standards are usually copyrighted and may be purchased from the originating organization or, if they are American National Standards, from the American National Standards Institute, 1430 Broadway, New York, NY 10018. 
NUREG/CR-2893

PNL-4395

$\mathrm{RH}$

\section{Correlation of Neutron Data Taken at Commercial Nuclear Sites}

Manuscript Completed: August 1983

Date Published: October 1983

Prepared by

L. A. Rathbun, G. W. R. Endres

Pacific Northwest Laboratory

Richland, WA 99352

Prepared for

Division of Facility Operations

Office of Nuclear Regulatory Research

U.S. Nuclear Regulatory Commission

Washington, D.C. 20555

NRC FIN B2423 


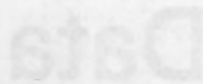 now $29+10$

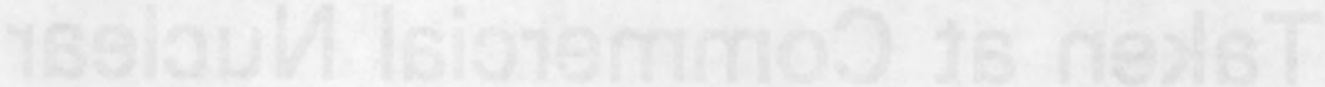

4

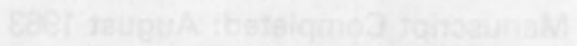

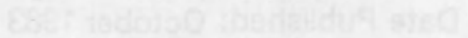

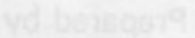

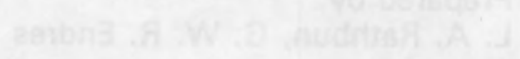

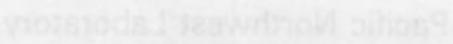

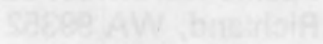

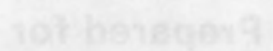

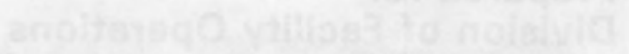

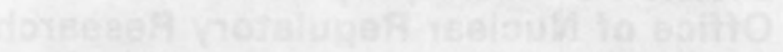

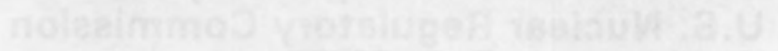

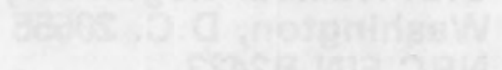

$+$

2 


\section{ABSTRACT}

In this report, data from neutron measurement and dosimetry studies performed by Pacific Northwest Laboratory, the Environmental Measurements Laboratory, and Rensselaer Polytechnic Institute are examined and compared. The purpose of this data correlation effort is to determine whether useful relationships exist between the actual neutron dose equivalent in a typical commercial nuclear power reactor and various measurement parameters, such as ratios of the response of 9-in. to 3-in. spheres, neutron/gamma ratios, albedo dosimeter response and neutron spectrometer readings. In most neutron radiation fields found in the reactors visited, the response of albedo dosimeters can be brought into reasonable agreement with dose equivalents measured with multispheres, tissue equivalent proportional counters (TEPCS) or remmeters. Because the responses of the remmeters, like the responses of albedo dosimeters, are energy dependent, it is preferable to correct the responses of the albedo dosimeters to agree with dose equivalents measured with either TEPCs or multispheres. If one of these laboratory systems has been used to measure neutron dose equivalents at a specific pressurized water reactor, a calculated average albedo dosimeter correction factor can be used for most locations at that reactor. However, if the measured $9-i n$. to $3-i n$. remmeter ratio is greater than 0.20 , it is advisable to use a plot of 9-in. to 3-in. remmeter ratios versus albedo dosimeter correction factors to obtain an albedo dosimeter correction factor. Because $9-i n$. to 3 -in. remmeter ratios at boiling water reactors are typically greater than 0.20 , the latter approach applies to this type of reactor. 


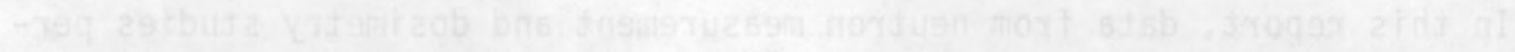

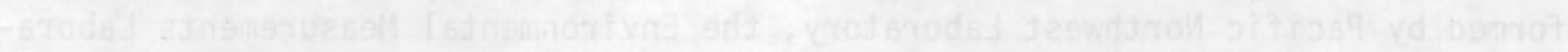

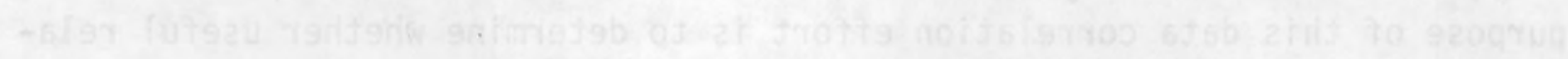

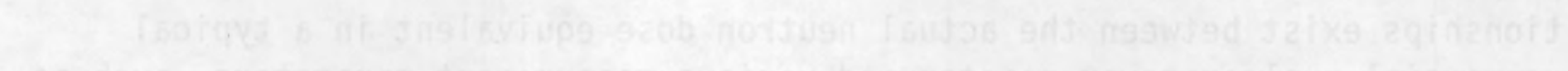

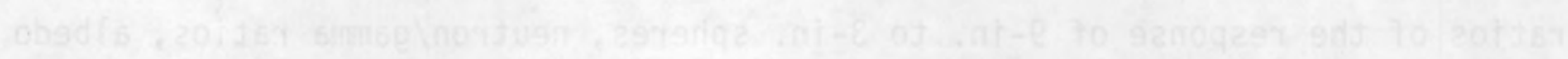

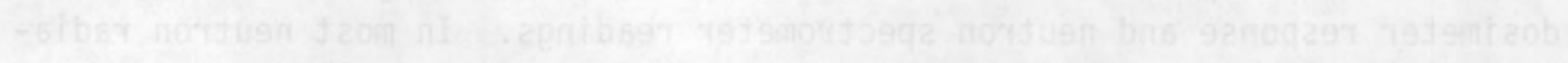

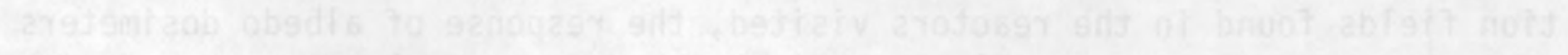

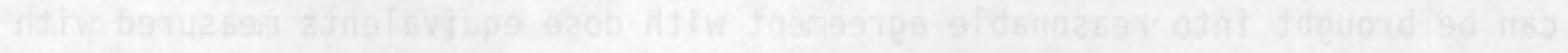

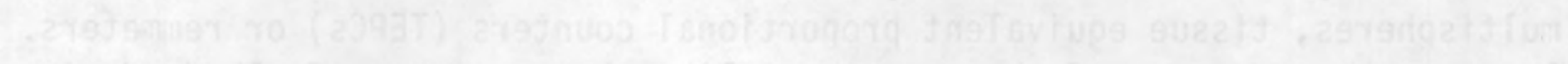

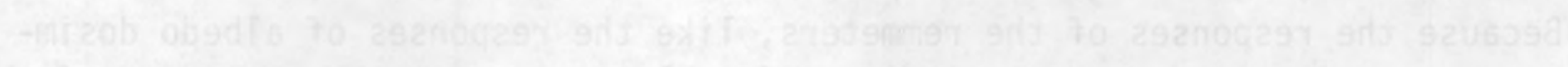

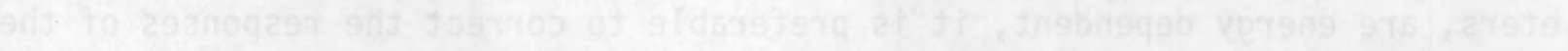

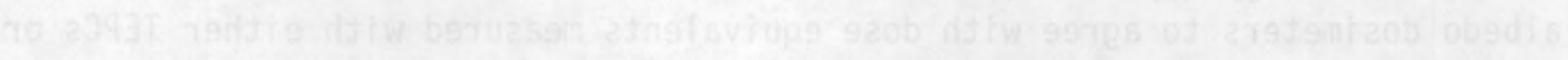

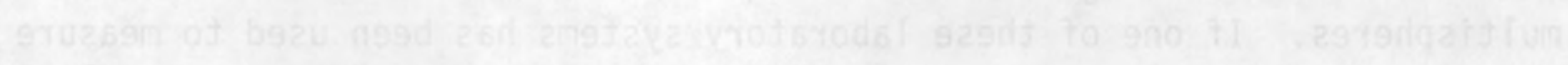

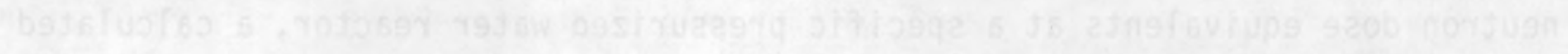

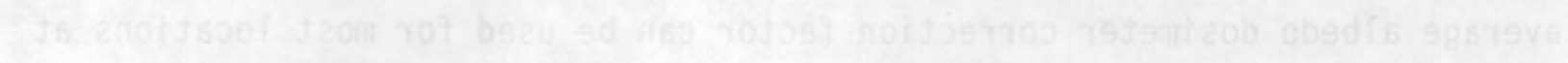

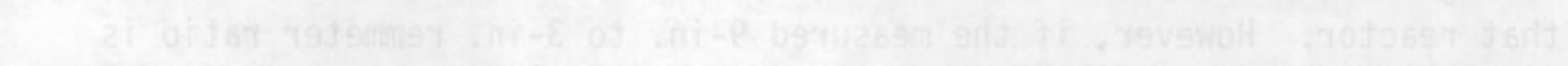

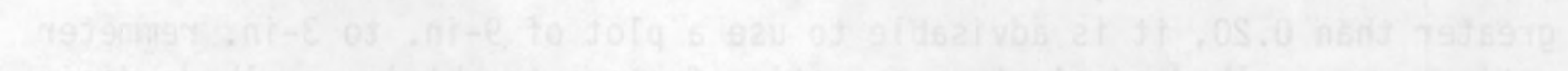

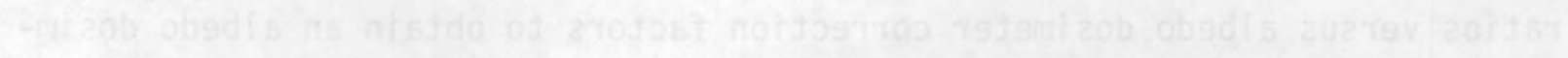
9074

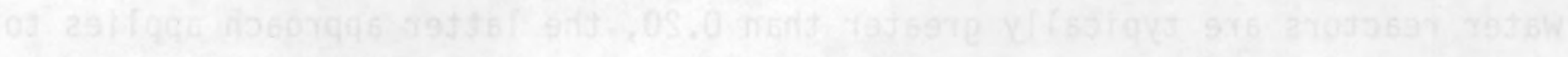

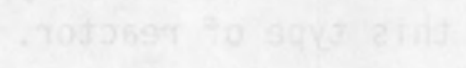




\section{CONTENTS}

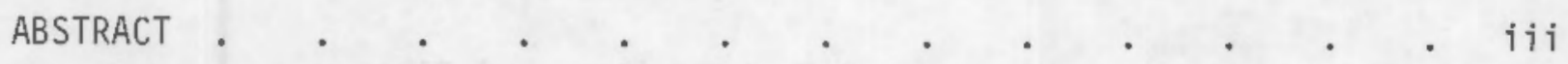

1.0 INTRODUCTION

2.0 SOURCES OF DATA $\quad \ldots \quad \ldots \quad \ldots \quad \ldots \quad$. $\quad . \quad \ldots$

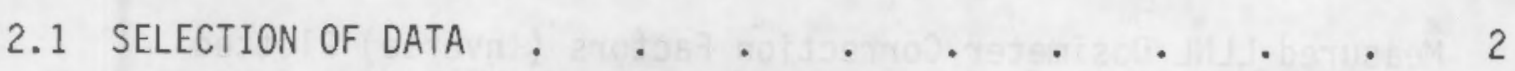

2.2 DISCUSSION OF TABLE 1 INFORMATION $. \quad . \quad . \quad . \quad$. 3

2.3 DISCUSSION OF TABLE 2 INFORMATION $. \quad . \quad . \quad . \quad . \quad 10$

2.4 DISCUSSION OF TABLE 3 INFORMATION $\quad . \quad \ldots \quad . \quad . \quad . \quad 12$

2.5 DISCUSSION OF TABLE 4 INFORMATION $. \quad . \quad . \quad . \quad . \quad 14$

2.6 DISCUSSION OF ANOMALOUS DATA $. \quad . \quad . \quad . \quad . \quad . \quad 16$

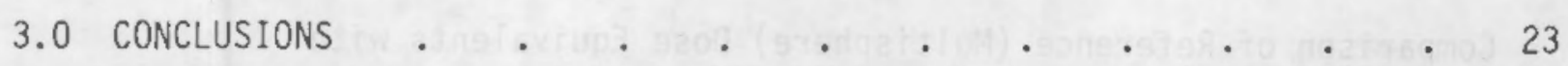

4.0 RECOMMENDATIONS . . . . . . . . . . . . . . . . . . 26

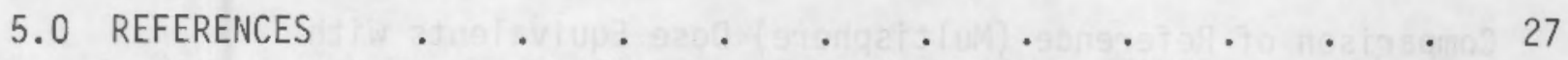




\section{FIGURES}

1 Measured PNL Dosimeter Correction Factors (Inverse) Plotted Against Measured 9-in. to 3-in. Sphere Response Ratios . . . 7

2 PNL Correction Curve From Laboratory Irradiations . . . . 7

3 Measured LLNL Dosimeter Correction Factors (Inverse) Plotted Against Measured 9-in. to 3-in. Sphere Response Ratios . . . 9

4 LLNL Correction Curve From Laboratory Irradiations . . 9

5 Measured Remmeter Correction Factors (Inverse) Plotted Against Measured 9-in. to 3-in. Sphere Response Ratios.

\section{$\underline{\text { TABLES }}$}

1 Comparison of Reference (Multisphere) Dose Equivalents with Albedo Dosimeter Responses and Survey Meter Responses and Ratios for PNL Data

2 Comparison of Reference (Multisphere) Dose Equivalents with Albedo Dosimeter Responses and Survey Meter Responses and Ratios for EML Data

3 Comparison of TEPC Dose Equivalents with Albedo Dosimeter Responses and Survey Meter Responses and Ratios for PNL Data .

4 Comparison of Alternate Multisphere Dose Equivalents with Albedo Dosimeter Responses and Survey Meter Responses and Ratios . . 15

5 Multisphere (Reference) and Albedo Dosimeter Dose Equivalents . 17

6 Comparison of TEPC, Multisphere and Remmeter Measurements Made During Subtask A and Subtask B . . . . . . . 22

7 Comparisons of Different Detectors in Multisphere Systems (EML Data) 


\subsection{INTRODUCTION}

Both Pacific Northwest Laboratory (PNL) and the Environmental Measurements Laboratory (EML) have conducted neutron spectrum measurements at nuclear power plant sites. The PNL study (NRC FIN B-2282) was undertaken at six nuclear power plants to measure and characterize neutron energy spectra, and to evaluate neutron radiation dose-equivalent rates where operating plant workers may be exposed to neutron radiation fields (Endres et a1. 1981). The EML study at eight nuclear power plants was more limited in scope. It was intended, primarily, to characterize the neutron environment inside the containment vessels of pressurized water power reactors (Sanna et a1. 1980). A portion of the data was provided by Rensselaer Polytechnic Institute (RPI) (NRC FIN B6651) (Ryan 1983).

There are several significant differences between the methods and devices used by PNL and EML in making neutron measurements at various power reactors. Perhaps the most important difference is that PNL placed numerous albedo personnel dosimeters on phantoms to evaluate the possible neutron dose-equivalent rates to workers. In contrast, EML relied primarily on multisphere results and previously published data to predict what the dosimeters might read in such a situation. A few albedo dosimeters were used by EML in the reactor containment areas for comparison with predicted results. Similarly, ElAL predicted neutron survey meter results, except for a few selected cases where actual readings were used for validation. Also, since the studies were designed to be complementary, only one reactor was visited by both EML and PNL.

However, similarities in the two studies make a comparison of results useful. Both relied on multispheres as the primary means of neutran spectral analyses, although EML used different detectors (TLDs and smal1 ${ }_{\text {LiI }} I(E u)$ scintillation detectors) in some cases rather than the single large ${ }_{\mathrm{LiI}(\mathrm{Eu})}$ scintillation detector employed by PNL. Both visited several pressurized water reactors. Both provide instances where multisphere, survey meter, and albedo dosimeter results exist for a common location. In two cases, EML and PNL conducted simultaneous multisphere measurements.

One purpose of this report to compare data from both the PNL and EML studies and examine the relationships between neutron spectra and dosimeter response and the ratio of the count rates obtained by inserting a BF- 3 slow neutron detector inside 3-inch and 9-inch spheres of polyethylene. Neutrongamma dose rate ratios and neutron survey meter responses were also compared with the parameters listed in the preceding sentence. 


\subsection{SOURCES OF' DATA}

The major portion of the data used in this study is from PNL's "Final Report on Subtask A" (Endres et a1. 1981), EML's "Neutron Measurements Inside PWR Containments" (Sanna et a1. 1980), and "Neutron Dosimeter Performance and Associated Calibrations at Nuclear Power Plants" (Schwartz et al. 1982). other sources of information include RPI's "Evaluation of Personnel Neutron Dosimetry at Operating Nuclear Power Plants" (Ryan 1983) and PNL's "Final Report on Subtask B" (Cummings et al. 1983), as well as additional data from PNL's notebooks and discussions with the authors of the publications noted above.

\subsection{SELECTION OF DATA}

Although there is a rather large volume of data available in the source documents described above, not all of it is useful for the purpose of this report. In particular, this report does not discuss specific neutron energy comparisons neutron flux, kerma, or other parameters related to spectral shape. The only parameter selected from the multisphere spectra is neutron dose-equivalent rate. The dose-equivalent rates are multiplied by exposure times to determine dose-equivalents. A total of 55 locations were considered in this report.

The dose-equivalents for many multisphere measurements reported in the source documents are listed in Tables 1, 2, and 4. In Tables 1 and 2 the multisphere data are based on the use of a large $(12.7 \times 12.7 \mathrm{~mm}){ }_{\mathrm{LiI}}$ (Eu) scintillation detector inside the spheres. Dose equivalents measured with this scintillation detector will be considered the "reference" dose equivalent, against which dose equivalents determined from other means are compared. In Table 3, the reference dose equivalent is not available. Therefore, dose equivalents based on tissue equivalent proportional counter (TEPC) measurements are substituted. Comparisons are discussed to attempt to determine whether a relationship between TEPC data and multisphere data exists. Similarly, in Table 4, multisphere dose equivalents derived from other than large

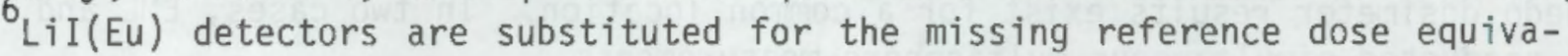
lents. This alternative multisphere data was measured using small (4 mm $x$ $4 \mathrm{~mm}){ }^{6} \mathrm{LiI}(\mathrm{Eu})$ detectors and RPI and EML TLD dosimeters which were placed at the center of the multispheres. It is important to note that the individual spheres of the multisphere set were normally separated by as much as one meter when TLDs were used for detectors. This could adversely affect results. PNL multisphere and TEPC dose-equivalents are reported only for those locations where PNL albedo dosimeter results were available. All the EML multisphere

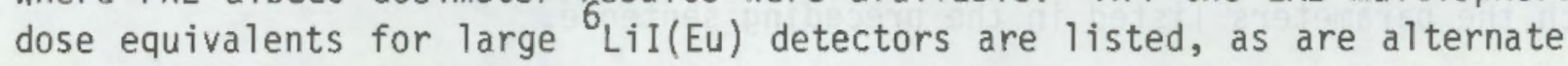
multisphere dose equivalents for those locations with albedo dosimeters. 
For all locations where Lawrence Livermore National Laboratory (LLNL) and/or PNL albedo dosimeters were placed on the front of a phantom, the results for these dosimeters were used. Both PNL and LLNL neutron dose equivalent dosimeter measurements were corrected with factors obtained from curves based on the relationship of $9-i n$. to $3-i n .(23-\mathrm{cm}$ to $7.6 \mathrm{~cm})$ remmeter ratios and albedo dosimeter responses to neutron sources, which have been compared with NBS standards. The PNL correction factors are designed to bring the dosimeter response into agreement with multisphere dose-equivalents, in contrast to the LLNL (Griffith et al. 1979) curve, which is derived from the relationship of the dosimeter response to the reading of the 9-in. spherical remmeter (Rascal).

All dose-equivalents determined with either SNOOPY remmeters or 9-in. spherical remmeters, at the listed multisphere and TEPC measurement locations, are also listed. The same may be said with respect to the ratio of 9-in. to $3-i n$. remmeter readings, the ratio of $10-i n$. to $3-i n$. sphere readings, and the ratios of the neutron dose equivalent rate to the gamma radiation dose rate determined from neutron and gamma survey meters.

In summary, all available parameters, excluding those mentioned earlier, which might be related to PNL or LLNL albedo dosimeter response and the "reference" dose equivalent are listed in the tables of this report. Not listed are the responses of commercial dosimeters evaluated by PNL in Subtask A and Subtask B of "Neutron Dosimetry at Commercial Nuclear Plants" (Endres et al. 1981 and Cummings et al. 1983). The similarities between the commercial albedo dosimeters and two DOE-laboratory developed albedo dosimeters are such that the general conclusions reached for the latter are valid for the former.

\subsection{DISCUSSION OF TABLE 1 INFORMATION}

All data presented in Table 1 were taken (either directly or via synthesis) from PNL's Subtask A report (Endres et al. 1981). Site $E$ is a BWR. All other sites are PWR's. Subscripts on $I_{1}$ and $I_{2}$ denote the first and second visits to site I. Although only one trip to sites $E$ and $G$ occurred during Subtask A, they have subscripts for later reference. Locations 4 4 and $8-8$ Site $I_{2}$ indicate that sets of dosimeters were placed at the same ${ }^{a}$ location on two successive days. The reference dose equivalent (Column 3 ) is obtained by multiplying the dose-equivalent rate from multispheres by the length of exposure time for the dosimeters. In subtracting the dose equivalent indicated by the corrected PNL dosimeter reading (Column 4) from the reference dose equivalent and dividing by the latter, we obtain the difference, $\Delta$, which is converted to $\%$ in Column 5 . This percentage difference varies from $5 \%$ to $107 \%$ of the reference dose equivalent, with an average 
TABLE 1. Comparison of Reference (Multisphere) Dose Equivalents with Albedo Dosimeter Responses and Survey Meter Responses and

Ratios for PNL Data

9-in. 10-in.

Ref. PNL Cyl. Spher LLNL to to

D. DOS Cyl. Spher

\begin{tabular}{|c|c|c|c|c|c|c|c|c|c|c|c|c|c|c|}
\hline Site & Location & $\begin{array}{l}\text { D.E. } \\
\text { mrem } \\
\end{array}$ & $\begin{array}{l}\text { Dos.D.E. } \\
\text { mrem }\end{array}$ & $\begin{array}{r}\Delta \\
\% \\
\end{array}$ & $\begin{array}{l}\text { D.E. } \\
\text { mrem }\end{array}$ & $\begin{array}{l}\text { D.E. } \\
\text { mrem }\end{array}$ & $\begin{array}{l}\text { D.E. } \\
\text { mrem }\end{array}$ & $\begin{array}{l}\Delta \\
\% \\
\end{array}$ & $\begin{array}{l}3 \text {-in. } \\
\text { Ratio } \\
\end{array}$ & $\begin{array}{l}3-\text { in. } \\
\text { Ratio } \\
\end{array}$ & $\begin{array}{c}n / \gamma \\
\text { Ratio } \\
\end{array}$ & $\stackrel{\div}{\operatorname{Ref} .}$ & $\stackrel{\div}{\text { Ref. }}$ & $\begin{array}{l}\text { Ave. } \\
\text { Fac. }\end{array}$ \\
\hline$E_{1}$ & $1-\times 29$ & 16 & 0.62 & 96 & 14 & 22 & 20 & 10 & 0.22 & 0.32 & 1.1 & 0.88 & 1.4 & \\
\hline$E_{1}$ & $2-\times 29$ & 40 & 48 & 20 & 32 & 46 & 40 & 13 & 0.26 & 0.41 & 0.8 & 0.80 & 1.2 & \\
\hline$E_{1}$ & $3-\times 29$ & 21 & NA & $N A$ & 18 & 29 & NA & NA & 0.22 & 0.32 & 0.7 & 0.86 & 1.4 & 3.8 \\
\hline $\mathrm{F}$ & 5 & 34 & 9 & 74 & 24 & 27 & 20 & 26 & 0.12 & 0.17 & 1.0 & 0.71 & 0.79 & \\
\hline$F$ & 10 & 9.6 & 12 & 20 & 32 & 36 & 30 & 17 & 0.11 & 0.11 & 1.0 & 3.3 & 3.8 & \\
\hline $\mathrm{F}$ & 11 & 3.6 & 7.1 & 97 & 11 & 21 & 20 & 5 & 0.24 & 0.06 & 0.8 & 3.1 & 5.8 & 13.0 \\
\hline $\mathrm{G}_{1}$ & 2 & 234 & 29 & 88 & 210 & 225 & 250 & 11 & 0.10 & 0.12 & 1.2 & 0.90 & 0.96 & \\
\hline$G_{1}$ & 3 & 196 & 161 & 18 & 210 & 224 & 310 & 38 & 0.10 & 0.15 & 2.8 & 1.1 & 1.1 & \\
\hline $\mathrm{G}_{1}$ & 9 & 136 & 92 & 32 & NA & 194 & 200 & 3 & 0.12 & 0.16 & 3.2 & NA & 1.4 & 13.1 \\
\hline $\mathrm{I}_{1}$ & 1 & 58 & 55 & 5 & 104 & 156 & 130 & 17 & 0.15 & NA & 2.0 & 1.8 & 2.7 & \\
\hline$I_{1}$ & 2 & 30 & 33 & 10 & 38 & 76 & 70 & 8 & 0.13 & NA & 3.0 & 1.3 & 2.5 & \\
\hline $\mathrm{I}_{1}$ & 3 & 14 & 12 & 14 & 33 & 33 & 40 & 21 & 0.12 & NA & 2.0 & 2.4 & 2.4 & 13.8 \\
\hline $\mathrm{I}_{2}$ & 1 & 3.4 & 1.7 & 50 & 5.0 & 13 & NA & NA & 0.14 & 0.20 & 0.22 & 1.5 & 3.8 & \\
\hline $\mathrm{I}_{2}$ & $4 a$ & 46 & 81 & 76 & 96 & 236 & 90 & 62 & 0.11 & 0.22 & 1.2 & 2.1 & 5.1 & \\
\hline $\mathrm{I}_{2}$ & $4 b$ & 55 & 59 & 7 & 115 & 283 & 110 & 61 & 0.11 & 0.22 & 1.2 & 2.1 & 5.1 & \\
\hline $\mathrm{I}_{2}$ & 7 & 85 & NA & NA & 246 & 520 & NA & NA & 0.10 & 0.18 & 1.7 & 2.9 & 6.1 & \\
\hline $\mathrm{I}_{2}$ & $8 a$ & 54 & 107 & 98 & 118 & 286 & 120 & 58 & 0.11 & 0.20 & 1.5 & 2.2 & 5.3 & \\
\hline $\mathrm{I}_{2}$ & $8 b$ & 67 & 139 & 107 & 146 & 353 & NA & NA & 0.11 & 0.20 & 1.5 & 2.2 & 5.3 & 25.5 \\
\hline J & 3 & 20 & 28 & 40 & 31 & NA & NA & NA & 0.16 & NA & 1.5 & 1.6 & NA & 16.3 \\
\hline
\end{tabular}




\author{
Notes for Table 1: \\ (1) Ref. D.E. = multisphere dose equivalent rates using large ${ }^{6} \mathrm{LiI}$ (Eu) detector $x$ \\ exposure time for dosimeters. \\ (2) PNL Dos. D.E. = The dose equivalent indicated by PNL albedo dosimeters, corrected \\ via 9 -in. to 3 -in. remmeter ratios. \\ (3) $\Delta \%=$ The difference between (1) and (2) above divided by (1) above. \\ (4) Cyl. O.E. = The dose equivalent rate indicated by the cyindrical (SNOOPY) \\ remmeter, multiplied by the dosimeter exposure times. \\ (5) Spher D.E. = The dose equivalent rate indicated by the spherical (Rascal) remmeter \\ multiplied by the dosimeter exposure times. \\ (6) LLNL D.E. = The dose equivalent indicated by the LLNL dosimeters, corrected via \\ $9-$ in. to $3-i n$. remmeter ratios. \\ (7) $\Delta \%=$ The difference between (5) and (6) above divided by (5) above. \\ (8) 9 -in. to 3 -in. Ratio $=$ The ratio of the Rascal remmeter measurement using the \\ ordinary $9-i n$. sphere to the remmeter measurement using the $3-i n$. cadmium covered \\ ball. \\ (9) 10-in. to $3-i n$. Ratio = The ratio of neutron count rates using the $10-i n$. and \\ 3-in. sphere from the multisphere set. \\ (10) $\mathrm{n} / \mathrm{\gamma}$ Ratio = The ratio of the neutron dose equivalent rate (from remmeter) to the \\ gamma exposure rate (from PNL cutie pie). \\ (11) Cyl $\div$ Ref. = (4) above divided by (1) above. \\ (12) Spher $\div$ Ref. = (5) above divided by (1) above. \\ (13) Ave. Fac. = The uncorrected PNL dosimeter dose equivalents divided by the \\ reference dose equivalents and averaged for each site.
}


of $50 \%$. Locations $E_{1} 1-X 29, F 11, G_{1} 2$, and $I_{2} 8$ have the largest variations for this comparison. At the first and last of these four locations, it was difficult to place the dosimeters in the same location as the multispheres. An alternate method of displaying the difference between the corrected dosimeter results and the ideal situation is shown in Figures 1 and 2. In Figure 1, the uncorrected PNL dosimeter responses are divided by the reference dose equivalents to obtain true correction factors. These results are plotted opposite the indicated 9 -in. to 3 -in. remmeter ratio. The best fit curve for this data appears to be a nearly horizontal line. This is in contrast to Figure 2, where the 9-in. to 3 -in. remmeter ratios versus the reciprocal of the dosimeter response correction factors developed from laboratory irradiations are plotted.

It has been pbserved that, for any plot of albedo dosimeter correction factors (inverse) ${ }^{(a)}$ versus the ratios of the $9-i n$. to $3-i n$. sphere responses where the 9 -in. to $3-i n$. ratio is less than 0.20 , the plot resembles a horizontal line. It is usually found that the midpoint of the horizontal line in Figure 1 falls on the lower end of a diagonal line extrapolated from calibration data versus $9-i n$. to $3-i n$. ratios from Figure 2 for the same dosimeter. This observation supports the argument for an average calibration factor in PWRs, where the 9-in. to $3-i n$. ratio is usually less than 0.20 . The horizontal spread in the PWR data points is thought to be a statistical phenomenon of the 9 -in. to $3-i n$. ratios.

The cylindrical (SNOOPY) remmeter and 9-in. spherical (Rascal) remmeter dose equivalents listed in Columns 6 and 7 of Table 1 have been divided by the reference dose equivalents to yield the results listed in the last two columns of the table. Excluding site $E$, the cylindrical remmeter dose equivalent is generally larger than that from the multisphere. Exceptions to this trend occur at locations F 5 and $G 2$. The average value of the SNOOPY/reference ratio is 1.8 . The average ratio of the spherical remmeter dose equivalent divided by the reference dose equivalent is 2.9. It is apparent that in some cases the two remmeters exhibit about the same results, but in other cases, the spherical remmeter result is up to 2.5 times that of the cylindrical remmeter. A bare $\mathrm{Cf}-252$ source, traceable to the National Bureau of Standards, was used to calibrate the remmeters whose results are listed in Tables 1 and 3. Calibration with the bare $\mathrm{Cf}-252$ or AmBe causes the remmeters to respond high in ordinary PWR neutron spectra. However, there was a slight underresponse of the cylindrical remmeter for BWR spectra.

(a) These correction factors are the same type of correction factors listed in previous PNL and LLNL publications. However, because the indicated albedo dosimeter response must be divided by these factors, they are designated as "inverse." A true "correction factor" would denote multiplication. 


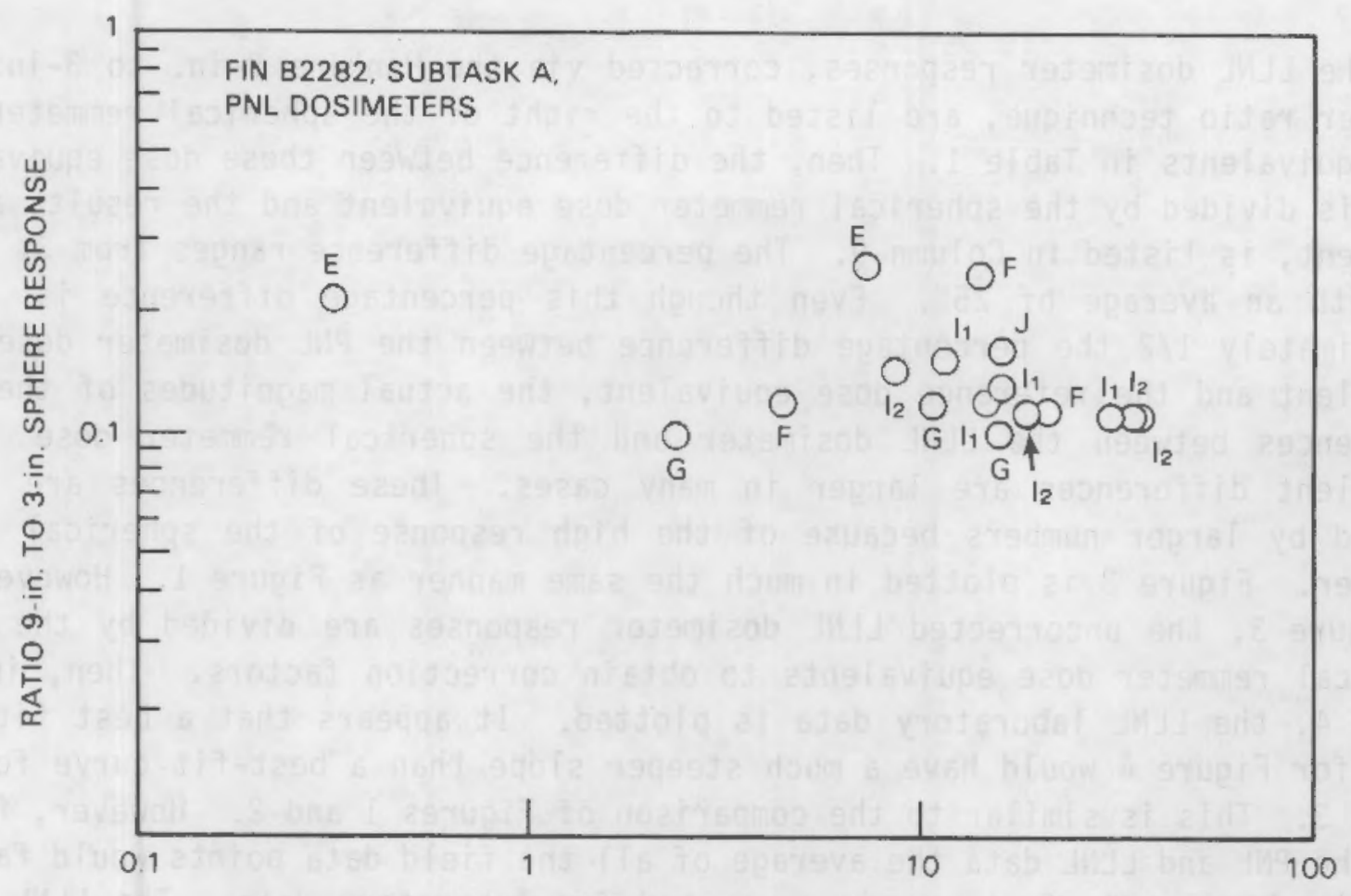

PNL ALBEDO DOSIMETER CORAECTION FACTOR (INVERSE)

FIGURE 1. Measured PNL Dosimeter Correction Factors (Inverse) Plotted Against Measured 9-in. to 3-in. Sphere Response Ratios

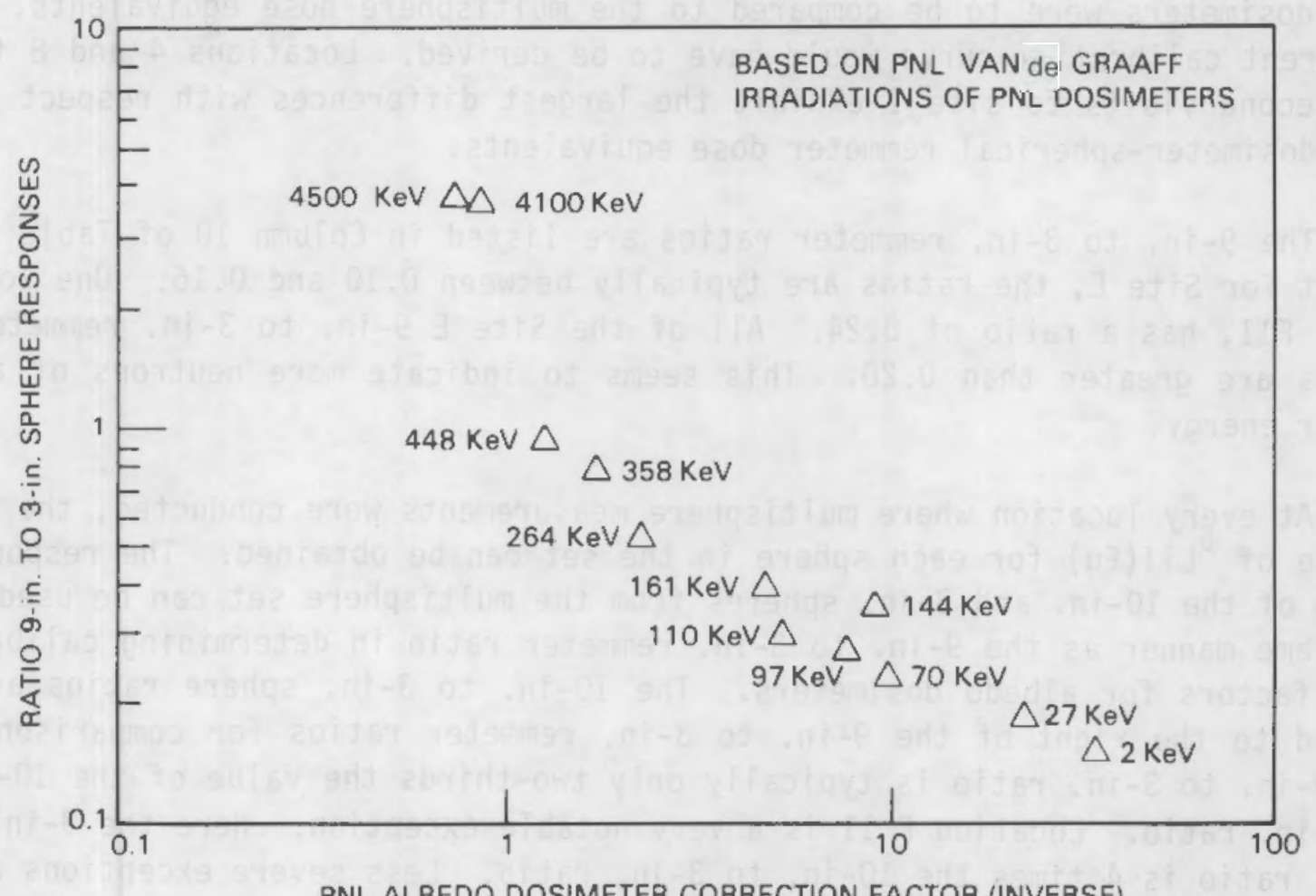

PNL ALBEDO DOSIMETER CORRECTION FACTOR (INVERSE)

FIGURE 2. PNL Correction Curve From Laboratory Irradiations 
The LLNL dosimeter responses, corrected via the Hankins 9-in, to 3-in. remmeter ratio technique, are listed to the right of the spherical remmeter dose equivalents in Table 1 . Then, the difference between these dose equivalents is divided by the spherical remmeter dose equivalent and the result, as a percent, is listed in Column 9. The percentage difference ranges from $3 \%$ to $62 \%$ with an average of $25 \%$. Even though this percentage difference is approximately $1 / 2$ the percentage difference between the PNL dosimeter dose equivalent and the reference dose equivalent, the actual magnitudes of the differences between the LLNL dosimeter and the spherical remmeter dose equivalent differences are larger in many cases. These differences are divided by larger numbers because of the high response of the spherical remmeter. Figure 3 is plotted in much the same manner as Figure 1. However in Figure 3, the uncorrected LLNL dosimeter responses are divided by the spherical remmeter dose equivalents to obtain correction factors. Then, in Figure 4, the LLNL laboratory data is plotted. It appears that a best fit curve for Figure 4 would have a much steeper slope than a best-fit curve for Figure 3. This is similar to the comparison of Figures 1 and 2 . However, for both the PNL and LLNL data the average of all the field data points would fall near the lower end of the curve generated for laboratory data. The LLNL dosimeters are compared to the spherical remmeter readings because the Hankins $9-i n$. to $3-i n$. ratio technique is based on laboratory measurements where the spherical remmeter was used to derive the neutron dose equivalent. If the LLNL dosimeters were to be compared to the multisphere dose equivalents, a different calibration curve would have to be derived. Locations 4 and 8 for the second visits to site I exhibit the largest differences with respect to LLNL dosimeter-spherical remmeter dose equivalents.

The 9-in. to 3 -in. remmeter ratios are Tisted in Column 10 of Table 1. Except for Site $E$, the ratios are typically between 0.10 and 0.16 . One Tocation, F11, has a ratio of 0.24 . All of the Site 59 -in. to 3 -in, remmeter ratios are greater than 0.20 . This seems to indicate more neutrons of a higher energy.

At every location where multisphere measurements were conducted, the response of $\mathrm{LiI(Eu)}$ for each sphere in the set can be obtained. The response ratio of the $10-i n$. and $3-i n$. spheres from the multisphere set can be used in the same manner as the 9-in. to 3 -in. remmeter ratio in determining calibration factors for albedo dosimeters. The 10-in. to 3 -in. sphere ratios are listed to the right of the 9-in. to 3-in. remmeter ratios for comparison. The $9-i n$. to $3-i n$. ratio is typically only two-thirds the value of the 10-in. to 3 -in. ratio. Location $F 11$ is a very notable exception. Here the 9-in. to 3 -in. ratio is 4 times the $10-i n$. to 3 -in. ratio. Less severe exceptions also exist for locations $F 10, G_{1} 2, I_{2} 4$ and $I_{2} 8$. 


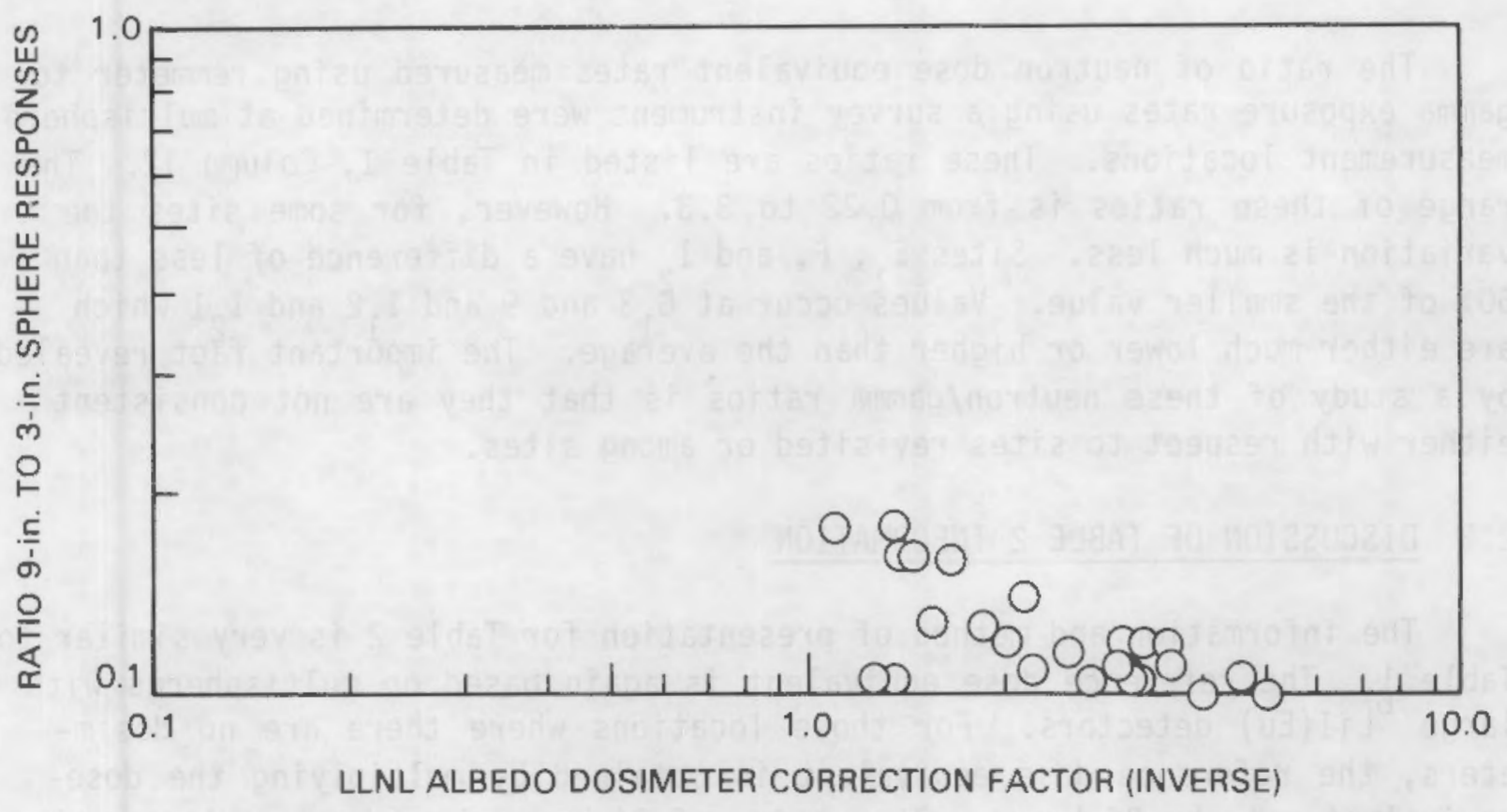

FIGURE 3. Measured LLNL Dosimeter Correction Factors (Inverse) Plotted Against Measured 9-in. to 3-in. Sphere Response Ratios

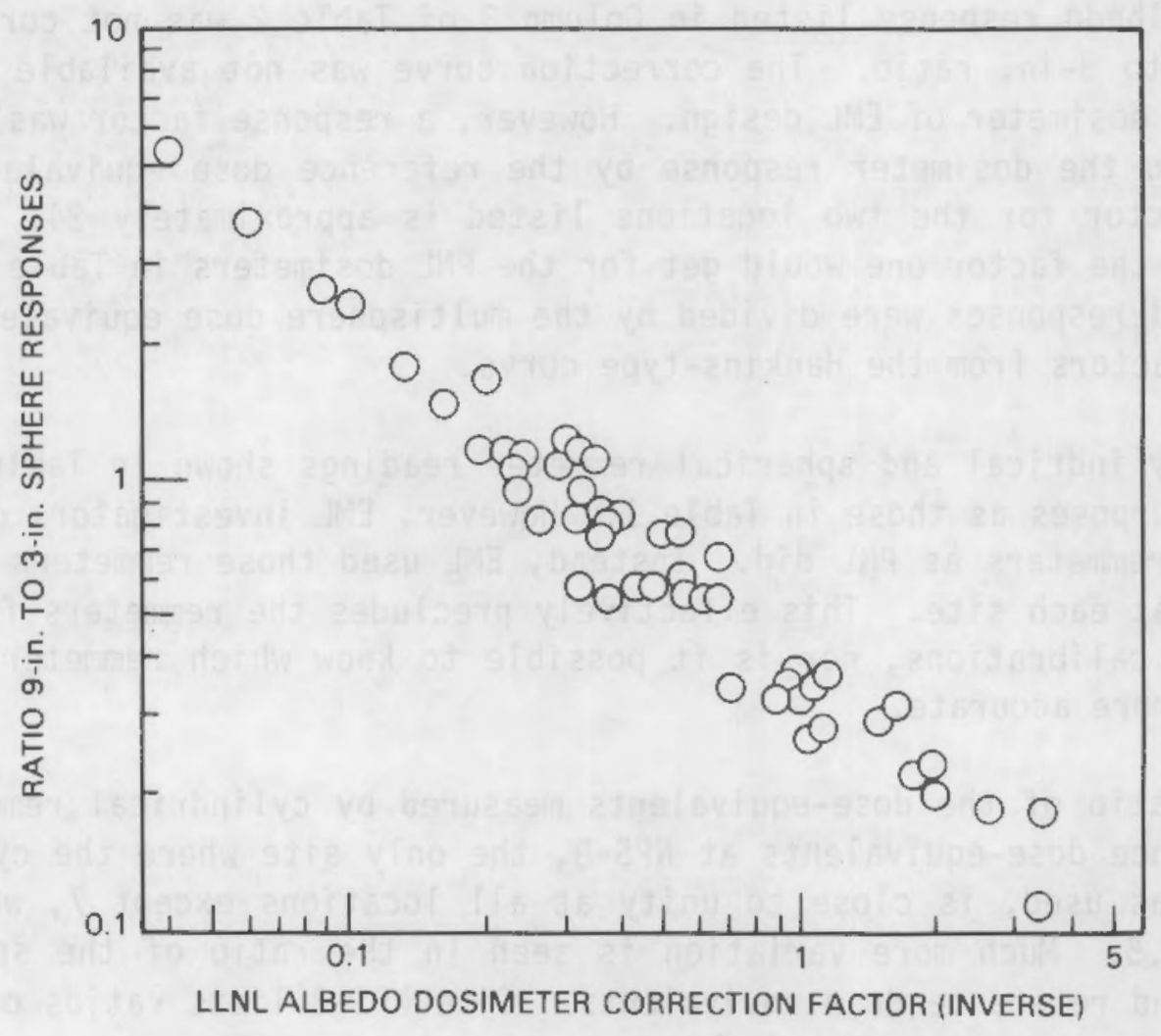

FIGURE 4. LLNL Correction Curve From Laboratory Irradiations 
The ratio of neutron dose equivalent ràtes measured using remmeter to gamma exposure rates using a survey instrument were determined at multisphere measurement locations. These ratios are listed in Table 1, Column 12 . The range of these ratios is from 0.22 to 3.3. However, for some sites the variation is much less. Sites $E_{1}, F$, and $I_{2}$ have a difference of less than $60 \%$ of the smaller value. Values occur at $G_{1} 3$ and 9 and $I_{1} 2$ and $I_{2} 1$ which are either much lower or higher than the average. The important fact revealed by a study of these neutron/gamma ratios is that they are not consistent either with respect to sites revisited or among sites.

\subsection{DISCUSSION OF TABLE 2 INFORMATION}

The information and method of presentation for Table 2 is very similar to Table 1 . The reference dose equivalent is again based on multispheres with large $\mathrm{LiI}(\mathrm{Eu})$ detectors. For those locations where there are no dosimeters, the reference dose equivalent is obtained by multiplying the doseequivalent rate by 24 hours. The choice of 24 hours is rather arbitrary, but does represent a reasonable length of exposure for dosimeters, had they been present. All data presented are from EML and RPI sources, except for survey meter readings at the common site, NPS-8.

The albedo response listed in Column 3 of Table 2 was not corrected by the 9-in. to $3-i n$. ratio. The correction curve was not available for this particular dosimeter of EML design. However, a response factor was determined by dividing the dosimeter response by the reference dose equivalent. The average factor for the two locations listed is approximately 24. This is similar to the factor one would get for the PNL dosimeters in Table 1 if their uncorrected responses were divided by the multisphere dose equivalents rather than the factors from the Hankins-type curve.

The cylindrical and spherical remmeter readings shown in Table 2 serve the same purposes as those in Table 1. However, EML investigators did not use their own remmeters as PNL did. Instead, EML used those remmeters that were available at each site. This effectively precludes the remmeters from having equivalent calibrations, nor is it possible to know which remmeter measurements are more accurate.

The ratio of the dose-equivalents measured by cylindrical remmeters to the reference dose-equivalents at NPS-8, the only site where the cylindrical remmeter was used, is close to unity at all locations except 7 , where the ratio is 3.5. Much more variation is seen in the ratio of the spherical remmeter and reference dose equivalents. Site NPS-3 1ists ratios of 15.5 and 7.3 , in contrast to site NPS- 4 where a ratio of only 0.51 occurs. 
TABLE 2. Comparison of Reference (Multisphere) Dose Equivalents with Albedo Dosimeter Responses and Survey Meter Responses and Ratios for EML Data

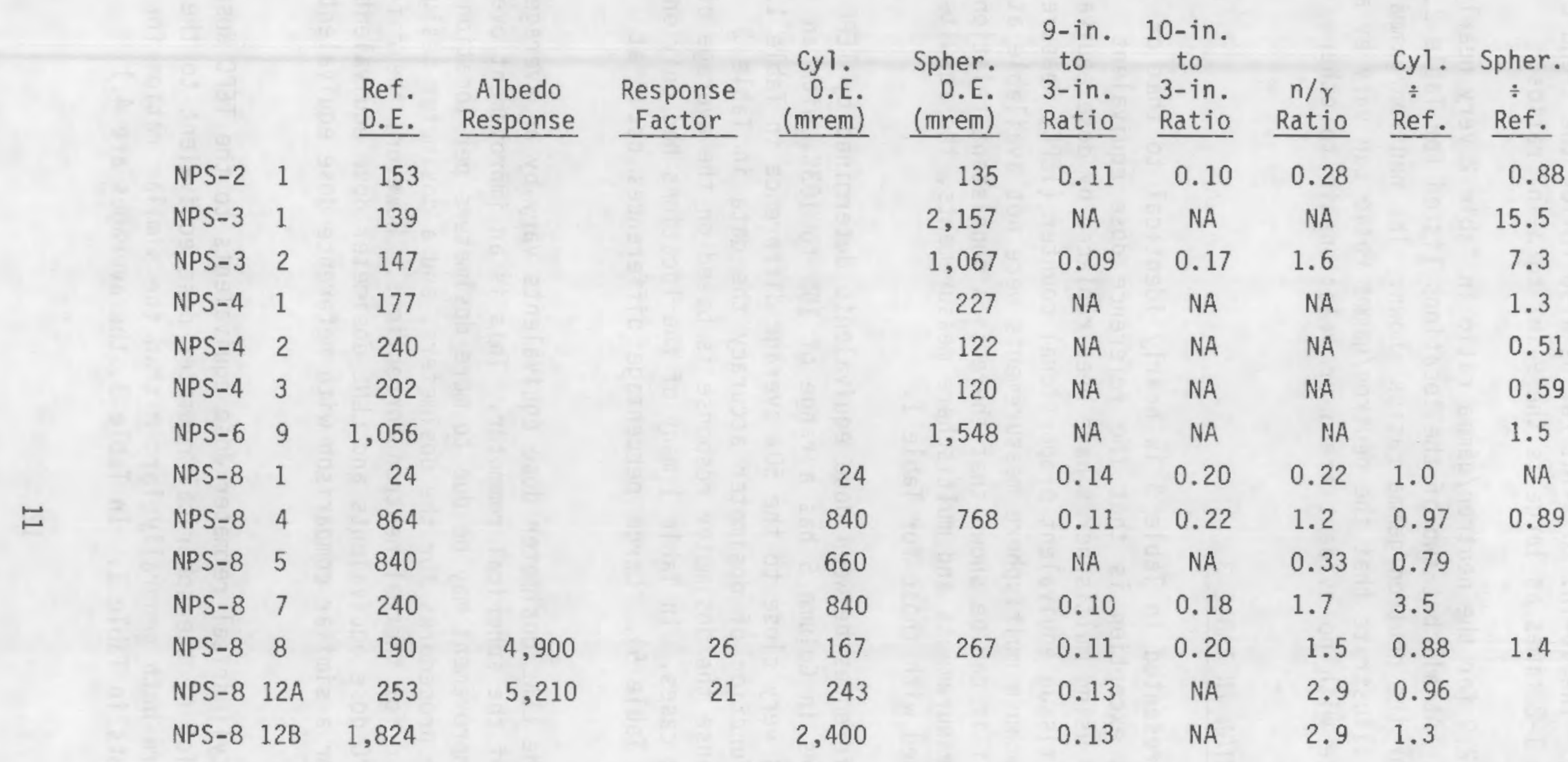

Notes for Table 2:

(1) See applicable notes in Table 1.

(2) Albedo Response = uncorrected EML albedo dosimeter response.

(3) Response Factor = albedo response divided by reference dose equivalent.

(4) All reference dose equivalents are obtained by multiplying the multisphere dose equivalent rate by 24 hours, except locations 8 and $12 \mathrm{~A}$ at site NPS-8. These latter two dose equivalent rates are multiplied by dosimeter exposure times. 
The 9-in. to 3-in. ratios in Table 2 are similar to those of Table 1 , but are more closely grouped. The $10-i n$. to $3-i n$. ratios also follow the trend of Table 1 in that they are 1-2 times as large as the 9-in. to 3 -in. ratios.

A range of 0.22 to 2.9 for the neutron/gamma ratio in Table 2 very nearly matches that of Table 1. At all but two of the locations listed for Table 2, PNL obtained the data for the neutron/ganma ratios shown. The neutron/gamma ratios listed for NPS-8 illustrate that the neutron/gamma ratio can vary by a factor of 10 at one site with no evident trend or relationship to other parameters.

\subsection{DISCUSSION INFORMATION IN TABLE 3}

The type of data presented in Table 3 is nearly identical to that of Table 1. The important exception is that the reference dose equivalent measurements obtained by using multispheres have been replaced by dose equivalents obtained by using tissue equivalent proportional counter (TEPC) measurements. This was done because multisphere measurements were not available at these TEPC locations. If it can be shown that there is a consistent relationship between the TEPC measurements and multisphere measurements, the results of Table 3 can be combined with those for Table 1.

The percentage differences between dose equivalents determined by TEPC and PNL albedo dosimeters in Column 5 has a range of $15 \%$ to $103 \%$, with an average of $51 \%$. This is very close to the $50 \%$ average difference in Table 1 . If it were strictly a function of dosimeter accuracy the data in Table 3 should be superior, because the dosimeter response is based on the average of five dosimeters, in most cases. In Table 1 many of the locations had only one or two dosimeters (see Table 5). Large percentage differences occur at Locations $\mathrm{H}_{4}$ and $\mathrm{I}_{3} 8$.

Also in Table 3 , the LLNL dosimeter dose equivalents vary by an average of only $19 \%$ from those of the spherical remmeter. This is an improvement over Table 1 results. The improvement may be due to more dosimeters per location, better quality assurance procedures for the dosimeters, and a dosimeter design which eliminates the need for thermal neutron corrections. However, the differences between the TEPC dose equivalents and LLNL dosimeter dose equivalents are even greater than for a similar comparison with reference dose equivalents in Table 1.

The ratios of the cylindrical remmeter dose equivalents to the TEPC dose equivalents and the ratios of the spherical remmeter dose equivalent to the TEPC dose equivalents are both generally larger than the similar ratios for reference dose equivalents in Table 1. In Table 3 , the averages are 4.1 
TABLE 3. Comparison of TEPC Dose Equivalents with Albedo Dosimeter Responses and Survey Meter Responses and Ratios for PNL DATA

\begin{tabular}{|c|c|c|c|c|c|c|c|c|c|c|c|c|}
\hline Site & Location & $\begin{array}{l}\text { TEPC } \\
\text { D.E. } \\
\text { mrem } \\
\end{array}$ & $\begin{array}{c}\text { PNL } \\
\text { Dos. D.E. } \\
\text { mrem } \\
\end{array}$ & $\%$ & $\begin{array}{l}\text { Cyl. } \\
\text { D.E. } \\
\text { mrem } \\
\end{array}$ & $\begin{array}{c}\text { Spher. } \\
\text { D.E. } \\
\text { mrem }\end{array}$ & $\begin{array}{l}\text { LLNL } \\
\text { D.E. } \\
\text { mrem }\end{array}$ & $\begin{array}{l}\Delta \\
\% \\
\end{array}$ & $\begin{array}{c}9-i n . \\
\text { to } \\
3-i n . \\
\text { Ratio }\end{array}$ & $\begin{array}{r}\mathrm{n} / \gamma \\
\text { Ratio }\end{array}$ & $\begin{array}{l}\text { Cy1. } \\
\div \\
\text { TEPC } \\
\end{array}$ & $\begin{array}{l}\text { Spher. } \\
\div \\
\text { TEPC }\end{array}$ \\
\hline$E_{2}$ & $1-\times 29$ & 23 & 13 & 43 & 30 & 37 & 35 & 5 & 0.22 & ${ }_{\infty}^{(3)}$ & 1.3 & 1.6 \\
\hline$E_{2}^{2}$ & $3-\times 29$ & 10 & 4.8 & 52 & 14 & 15 & 16 & 7 & 0.22 & ${ }_{\infty}(3)$ & 1.4 & 1.5 \\
\hline $\mathrm{G}_{2}$ & 2 & 8.1 & 9.5 & 17 & 40 & 25 & $2 i$ & 4 & 0.11 & 4.0 & 13.3 & 8.3 \\
\hline $\mathrm{G}_{2}$ & 9 & 20 & 17 & 15 & 50 & 43 & 43 & 0 & 0.11 & 5.8 & 2.5 & 2.2 \\
\hline $\mathrm{G}_{2}$ & 15 & 192 & 157 & 18 & 350 & 299 & 421 & 41 & 0.11 & 12 & 1.8 & 1.6 \\
\hline $\mathrm{H}$ & 3 & 300 & 413 & 38 & 712 & NA & 830 & NA & 0.12 & $\begin{array}{l}4.5 \\
1.4\end{array}$ & 2.4 & NA \\
\hline H & 4 & 493 & 999 & 103 & 3200 & NA & 2310 & NA & 0.15 & 1.7 & 6.5 & NA \\
\hline $\mathrm{I}_{1}$ & 4 & 702 & 1069 & 52 & 1630 & 2006 & 2310 & 15 & 0.18 & 8.2 & 2.3 & 2.9 \\
\hline$I_{1}$ & 5 & 357 & 511 & 43 & 800 & 1182 & 855 & 28 & 0.16 & 4.1 & 2.2 & 3.3 \\
\hline $\mathrm{I}_{3}$ & 4 & 24 & 41 & 71 & 110 & 85 & 121 & 42 & 0.14 & 1.6 & 4.6 & 3.5 \\
\hline $\mathrm{I}_{3}$ & 8 & 33 & 66 & 100 & 160 & 125 & 151 & 21 & 0.14 & 3.1 & 4.8 & 3.8 \\
\hline $\mathrm{I}_{3}$ & 10 & 203 & 301 & 48 & 1380 & 1023 & 827 & 19 & 0.14 & 4.0 & 6.8 & 5.0 \\
\hline$I_{3}$ & $12 \mathrm{~A}$ & 81 & 130 & 60 & 370 & 243 & 322 & 33 & 0.14 & 4.8 & 4.6 & 3.0 \\
\hline
\end{tabular}

Notes for Table 3:

(1) See Table 1 notes.

(2) TEPC data is substituted for all reference dose equivalents.

(3) Gamma dose rate was too low to observe on the gamma survey meter.

$E_{2}=$ Second trip to Site $E$ (performed under Subtask 8).

$\mathrm{G}_{2}^{2}=$ Second strip to Site G (performed under Subtask B).

$I_{1}^{2}=$ First trip to Site I (performed under Subtask A).

$\mathrm{I}_{3}=$ Third trip to Site I (performed under Subtask B). 
and 3.3 , respectively. It is notable that in Table 3 there are many cases where the cylindrical remmeter dose equivalent is larger than the spherical remmeter dose equivalent, in contrast to Table 1, where the opposite is consistently true. Site $G_{2} 2$ has very large ratios for cylindrical and spherical remmeters in Table 3.

Of the 9-in. to 3 -in. ratios listed in Table 3, only those listed for Sites $H$ and $I_{1}$ are actual Subtask B measurements. All the others are average values derived from Subtask A data. Data for 3-in. spherical remmeter measurements were not available for Sites $E_{2}, G_{2}$ and $I_{3}$. Hence, there is less variation than might otherwise be the case. The two site I ratios are higher than one might expect based on Table 1 data for the same site. There are no 10-in. to 3-in. multisphere ratios for this table.

The neutron/gamma ratio in Table 3 ranges from 1.4 to 12 or $\infty$, depending on whether site $E$ ratios are used. There seems to be little consistency among locations at any given site. At location $\mathrm{H} 3$ the two readings vary by a factor of 3. For locations where neutron/gamma ratios were obtained on successive trips, the Table 3 ratios are all larger than the Table 1 values. The apparent increase is about $150 \%$ on the average. Of course, site $E$ had no measurable gamma radiation at the survey locations on the second trip.

\subsection{DISCUSSION OF INFORMATION IN TABLE 4}

Table 4 contains the same kind of information as Table 2. However, the reference dose equivalents were not available. Therefore, alternate dose equivalents based on multisphere measurements with small $\mathrm{LiI}(\mathrm{Eu})$ detectors, EML albedo dosimeters and Rensselaer Polytechnic Institute (RPI) albedo dosimeters have been substituted. If the alternate dose equivalents can be shown to approximate the reference dose equivalents, the results for Tables 2 and 4 can be combined.

In Table 4, the response factors calculated for EML's albedo dosimeters average approximately 28 for site NPS -6 and 48 for site NPS-5. Unfortunately, there is no PNL data for these sites, so a comparison of dosimeter responses is not possible. The NPS-6 average does agree well with the average for NPS-8.

When the cylindrical remmeter dose equivalents are divided by the alternate dose equivalents the results are quite different for NPS-5 compared to NPS-6. The average ratio (0.69) at site NPS-6 is lower than that at any other EML or PNL site, including the BWR. The 2.9 average ratio at NPS -5 is high compared to Tables 1 and 2, but low compared to Table 3. The spherical remmeter dose equivalent to alternate dose equivalent ratios at NPS-6 are similar to most Table 1 and Table 3 sites. 
TABLE 4. Comparison of Alternate (Multisphere) Dose Equivalents with Albedo Dosimeter Responses and Survey Meter Responses and Ratios

\begin{tabular}{|c|c|c|c|c|c|c|c|c|c|c|c|}
\hline & & $\begin{array}{l}\text { Alt. } \\
\text { D.E. }\end{array}$ & $\begin{array}{r}\text { Albedo } \\
\text { Response } \\
\end{array}$ & $\begin{array}{l}\text { Response } \\
\text { Factor } \\
\end{array}$ & $\begin{array}{r}\text { Cyl. } \\
\text { D.E. } \\
\text { (mrem) } \\
\end{array}$ & $\begin{array}{c}\text { Spher. } \\
\text { D.E. } \\
\text { (mrem) } \\
\end{array}$ & $\begin{array}{l}\text { to } \\
3-i n . \\
\text { Ratio }\end{array}$ & $\begin{array}{r}\text { to } \\
3-i n . \\
\text { Ratio } \\
\end{array}$ & $\begin{array}{c}n / \gamma \\
\text { Ratio } \\
\end{array}$ & $\begin{array}{l}\text { Cyl. } \\
\vdots \\
\text { Alt. } \\
\end{array}$ & $\begin{array}{c}\text { Spher. } \\
\div \\
\text { Alt. }\end{array}$ \\
\hline NPS-5 & 1 & 90 & 4990 & 55 & 300 & & & 0.14 & 0.22 & 3.3 & \\
\hline NPS-5 & 2 & 1720 & 74390 & 43 & 3406 & & & 0.10 & 0.18 & 2.0 & \\
\hline NPS-5 & 3 & 54 & 2500 & 46 & 180 & & & 0.10 & 1.5 & 3.3 & \\
\hline NPS-6 & 1 & 192 & 5290 & 28 & 122 & 297 & & & & 0.64 & 1.5 \\
\hline NPS- 6 & 2 & 101 & 2990 & 30 & 71 & 129 & & & 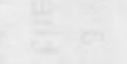 & 0.70 & 1.3 \\
\hline NPS-6 & 3 & 173 & 4265 & 25 & 125 & 356 & & 0.07 & 0.40 & 0.72 & 2.1 \\
\hline
\end{tabular}

Notes for Table 4:

(1) See Table 2 notes.

(2) Alternate (Alt.) dose equivalents are based on all available multisphere measurements at each location, except that no multispheres contained the large LiI(Eu) detector. 
There are no 9-in. to 3 -in. remmeter ratios for Table 4 . The $10-i n$. to 3-in. sphere ratios vary from 0.07 at NPS-6 to 0.14 at NPS-5. They are somewhat lower than the ratios in Tables 1 and 2 .

The neutron/gamma ratios in Table 4 range from 0.18 to 1.5 .

\subsection{DISCUSSION OF ANOMALOUS DATA}

In Table 1, Location E 1-X29 has a very low value for the corrected PNL dosimeter dose equivalent. However, the 9-in. to 3-in., 10-in. to 3-in., cylindrical and spherical remmeters and LLNL dosimeters all have values that correlate well with each other and with the reference dose equivalent. Therefore, it is probable that the PNL dosimeter readings are low. Only two dosimeters are involved and one reads zero (Table 5).

At Location F 5 (Table 1), the PNL dosimeter corrected dose equivalent is again low. However, in this case, the 9-in. to 3-in. and 10-in. to 3-in. ratios do not correlate with the remmeter/reference ratios. The remmeters, especially the spherical remmeter, may read low.

Location F 11 (Table 1) has a high value for the corrected PNL dosimeter dose equivaient. In addition, the 9-in. to 3-in. and 10-in. to 3-in. ratios do not correlate. The $9-i n$. to 3 -in. ratio is much higher than any other 9-in. to 3-in. ratio listed for PWRs, but the $10-i n$. to 3 -in. ratio is the lowest in the table. The high ratio of the spherical remmeter dose equivalent compared to the reference and cylindrical remmeters seem to indicate that the 9 -inch spherical remmeter reading may be in error. Also the commercial survey meter used to make the $9-i n$. to $3-i n$. ratio measurements could have malfunctioned; this instrument has been known to malfunction during other measurements.

Location G, 2 (Table 1) has a very low corrected PNL dosimeter dose equivalent. Because the two remmeters have similar dose equivalents and both are low relative to the reference dose equivalent, the $9-i n$. to 3 -in. ratio could be expected to be similar to those at Site E. However, the 9-in. to 3-in. and 10-in. to 3-in. ratios are about one-half those at site $E$. It is evident that the PNL dosimeter results are quite low.

Location $I_{2} 8$ (Table 1) (both measurements) also has a large difference between the reference and PNL dosimeter results. The 9-in. to 3-in. ratios appear to be low compared to the 10-in. to 3-in. ratios. However, an even lower 9-in. to $3-i n$. is needed to bring the PNL dosimeters into agreement with the reference dose equivalent. Also, the dose equivalent for the spherical remmeter is high compared to the reference and cylindrical remmeter doseequivalents. Hence, the major error is probably in the PNL dosimeters. 
TABLE 5. Multisphere (Reference) and Albedo Dosimeter Dose Equivalents

\begin{tabular}{|c|c|c|c|c|}
\hline Site & Loc. & $\begin{array}{c}\text { Ref. } \\
\text { D.E. (mrem) } \\
\end{array}$ & $\begin{array}{c}\text { PNL } \\
\text { Alb. Dos. } \\
\text { D.E. (mrem) }\end{array}$ & $\begin{array}{l}\text { LLNL (Corrected) } \\
\text { Alb. Dos. } \\
\text { D.E. (mrem) } \\
\end{array}$ \\
\hline $\mathrm{E}_{1}$ & $1-\times 29$ & 15.5 & $\begin{array}{r}10 \\
0\end{array}$ & 20 \\
\hline$E_{1}$ & $2-\times 29$ & 40.5 & $\begin{array}{l}390 \\
190\end{array}$ & 40 \\
\hline $\mathrm{E}_{1}$ & $3-\times 29$ & 21.0 & NA & NA \\
\hline$E_{2}$ & $1-\times 20$ & NA & $\begin{array}{r}90 \\
100 \\
100 \\
120 \\
100\end{array}$ & 40 \\
\hline$E_{2}$ & $3-\times 29$ & NA & $\begin{array}{l}33 \\
41 \\
26 \\
47 \\
47\end{array}$ & $\begin{array}{l}16 \\
17 \\
16\end{array}$ \\
\hline$F$ & 1 & NA & 90 & 10 \\
\hline $\mathrm{F}$ & 5 & 34.0 & 150 & 20 \\
\hline $\mathrm{F}$ & 10 & 9.6 & 200 & 30 \\
\hline$F$ & 11 & 3.6 & 50 & 20 \\
\hline$G_{1}$ & 2 & 234 & 550 & 250 \\
\hline $\mathrm{G}_{1}$ & 3 & 196 & 3,050 & 310 \\
\hline$G_{1}$ & 9 & 136 & $\begin{array}{l}1,100 \\
1,820\end{array}$ & 200 \\
\hline$G_{1}$ & 15 & NA & $\begin{array}{l}19,180 \\
20,480\end{array}$ & 2,660 \\
\hline $\mathrm{G}_{1}$ & 22 & NA & $\begin{array}{l}190 \\
320\end{array}$ & 20 \\
\hline
\end{tabular}


TABLE 5. (continued)

\begin{tabular}{|c|c|c|c|c|}
\hline Site & Loc. & $\begin{array}{l}\text { Ref. } \\
\text { D.E. (mrem) }\end{array}$ & $\begin{array}{c}\text { PNL } \\
\text { Alb. Dos. } \\
\text { D.E. (mrem) }\end{array}$ & $\begin{array}{l}\text { LLNL (Corrected) } \\
\text { Alb. Dos. } \\
\text { D.E. (mrem) } \\
\end{array}$ \\
\hline $\mathrm{G}_{2}$ & 2 & NA & $\begin{array}{l}160 \\
150 \\
160 \\
180 \\
170\end{array}$ & $\begin{array}{l}25 \\
24 \\
24 \\
25\end{array}$ \\
\hline $\mathrm{I}_{1}$ & 8 & NA & $\begin{array}{l}27,040 \\
23,700\end{array}$ & 3,980 \\
\hline $\mathrm{I}_{1}$ & 10 & NA & $\begin{array}{l}26,500 \\
36,300\end{array}$ & 6,100 \\
\hline $\mathrm{I}_{2}$ & 1 & 3.4 & $\begin{array}{l}20 \\
30 \\
20 \\
50\end{array}$ & NA \\
\hline $\mathrm{I}_{2}$ & $4 a$ & 45.5 & $\begin{array}{l}1,570 \\
1,220\end{array}$ & 90 \\
\hline $\mathrm{I}_{2}$ & $4 b$ & 54.6 & $\begin{array}{r}840 \\
1,190\end{array}$ & 110 \\
\hline $\mathrm{I}_{2}$ & 6 & NA & $\begin{array}{l}2,630 \\
2,640\end{array}$ & $\begin{array}{l}260 \\
250\end{array}$ \\
\hline $\mathrm{I}_{2}$ & 7 & 85.0 & NA & NA \\
\hline $\mathrm{I}_{2}$ & $8 a$ & 54.4 & $\begin{array}{l}1,350 \\
2,350\end{array}$ & 120 \\
\hline $\mathrm{I}_{2}$ & $8 b$ & 67.3 & $\begin{array}{l}3,130 \\
1,640\end{array}$ & NA \\
\hline $\mathrm{I}_{2}$ & 10 & NA & $\begin{array}{l}3,370 \\
2,950\end{array}$ & 430 \\
\hline $\mathrm{I}_{2}$ & 12 & NA & $\begin{array}{l}17,000 \\
16,690\end{array}$ & 1,570 \\
\hline $\mathrm{I}_{3}$ & 4 & NA & $\begin{array}{l}580 \\
540 \\
500 \\
600 \\
370\end{array}$ & $\begin{array}{l}121 \\
121 \\
121\end{array}$ \\
\hline
\end{tabular}


TABLE 5. (continued)

\begin{tabular}{|c|c|c|c|c|}
\hline Site & Loc. & $\begin{array}{l}\text { Ref. } \\
\text { D.E. (mrem) }\end{array}$ & $\begin{array}{c}\text { PNL } \\
\text { Alb. Dos. } \\
\text { D.E. (mrem) } \\
\end{array}$ & $\begin{array}{l}\text { LLNL (Corrected } \\
\text { Alb. Dos. } \\
\text { D.E. (mrem) } \\
\end{array}$ \\
\hline $\mathrm{I}_{3}$ & 8 & NA & $\begin{array}{l}970 \\
900 \\
910 \\
880 \\
690\end{array}$ & $\begin{array}{l}151 \\
160 \\
141\end{array}$ \\
\hline $\mathrm{I}_{3}$ & 10 & $N A$. & $\begin{array}{l}4,130 \\
4,610 \\
3,880 \\
4,480 \\
2,740\end{array}$ & $\begin{array}{l}789 \\
858 \\
835\end{array}$ \\
\hline $\mathrm{I}_{3}$ & $12 \mathrm{~A}$ & NA & $\begin{array}{l}1,270 \\
1,740 \\
1,290 \\
2,020 \\
2,240\end{array}$ & $\begin{array}{l}310 \\
334 \\
322\end{array}$ \\
\hline $\mathrm{J}$ & 1 & NA & $\begin{array}{l}288 \\
289\end{array}$ & NA \\
\hline J & $1 \mathrm{~A}$ & $N A$ & 147 & NA \\
\hline J & 2 & NA & $\begin{array}{l}387 \\
427\end{array}$ & 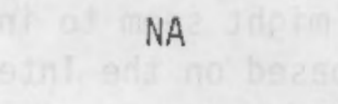 \\
\hline$J$ & 3 & 19.7 & $\begin{array}{l}238 \\
404 \\
320\end{array}$ & NA \\
\hline
\end{tabular}


(There was a factor of 2 difference between each pair of PNL dosimeters at this location.) This seems to indicate a problem with the placement of the dosimeters and a rapidly varying neutron field.

At Location $I_{2}, 4_{a}$, and $4_{b}$ (Table 1 ), the 9-in. to 3 -in. ratios are low relative to the $10-i n$. to 3 -in. ratios. However, the spherical remmeter dose equivalent is high relative to the LLNL dosimeter, the reference, and the cylindrical remmeter dose equivalents. The 3-in. remmeter dose equivalents may be high.

I, 7 (Table 1) and NPS-8, Location 7 (Table 2) are the same location and the EML and PNL data both show high cylindrical remmeter dose equivalents compared to the reference. I, 7 also has a similar spherical remmeter overresponse. This would suggest low neutron energies.

Locations NPS-3 1 and 2 (Table 2) have very high spherical remmeter dose equivalents relative to the reference dose equivalent, but at NPS-4 2 the opposite condition exists. In all cases the assumption is that the spherical remmeter reading is in error. The low $9-i n$. to 3 -in. ratio at NPS-3 2 does not correlate with a high remmeter reading.

At location $G_{2} 2$ (Table 3 ) the remmeters have much larger dose equivalents than the TEPC dose equivalent. In addition, the low 9-in. to 3-in. ratio and low TEPC dose equivalent relative to the PNL dosimeter dose equivalent might seem to indicate that the TEPC did (Bgt respond correctly. However, based on the Interim Report of Subtask $B$, it is known that there was a $40 \%$ reduction in dose equivalent rate at Site $G$ between the two visits (see Table 6). This would tend to increase the overresponse of the remmeters, although probably not of the magnitude indicated. The cylindrical remmeter reads higher in this case than the spherical remmeter, indicating a possible calibration problem. This situation is repeated throughout the $\mathrm{G}_{2}$ and $\mathrm{I}_{3}$ data. Also, in a direct comparison at Site $G_{2}$ during Task A (Endres et a 1 . 1981), the TEPC read only $69 \%$ of the multisphere dose equivalent rate, and the TEPC dose equivalent rate at the same location in Subtask B (Cummings et a 1. 1982 ) is $25 \%$ rather than $60 \%$ of the Subtask $A$ value. It must be noted, too, that the $9-i n$. to $3-i n$. values listed for Sites $E_{2}, G_{2}$, and $I_{3}$ are based on the averages of Subtask $A$ measurements rather than Subtask $B$ and therefore may not be truly representative.

(b) Endres, G. W. R., J. M. Aldrich and R. V. Griffith. 1980-unpublished. Interim Report-Neutron Dosimetry at Commercial Nuclear Sites Study. Pacific Northwest Laboratory, Richland, Washington. 
The situation at all the $I_{3}$ locations in Table 3 is similar to that for $\mathrm{G}_{2} 2$, with an important exception. At two locations, 4 and 8 , the TEPC readings are consistent at Site I for all three trips. However, the remmeter readings are considerably different for the three visits. The shielding added between visits 1 and 2 might account for the change in remmeter response noted for visit number two, but there is no known reason for the additional increase in response of the cylindrical remmeter for the third visit, especially with the decrease in the spherical remineter response. It is suspected that the problem might lie with the cylindrical remmeter in this case.

At the two $E_{2}$ (Table 3) locations, the cylindrical remmeter-TEPC dose equivalent ratios are about $50 \%$ greater than in $\mathrm{E}_{1}$. However, the relative spherical remmeter response has increased much less.

Finally, Site $\mathrm{H}$ (Table 3), which was visited under Subtask $A$, has one location (4) where the cylindrical remmeter dose equivalent is more than a factor of 6 higher than that of the TEPC and another location where the same comparison yields a ratio of 2.4. In this case, there is no second trip and no direct multisphere-TEPC comparison. The 9 -in. to 3 -in. ratios seem reasonable, so there is no indication whether the remmeter or the TEPC is in error at Location $\mathrm{H} 4$. 
TABLE 6. Comparison of TEPC, Multisphere and Remmeter Measurements Made During Subtask A and Subtask B

\begin{tabular}{|c|c|c|c|c|c|c|c|}
\hline \multirow[b]{2}{*}{ Location } & \multicolumn{4}{|l|}{ Multi- } & \multicolumn{3}{|c|}{ Subtask B } \\
\hline & $\begin{array}{c}\text { sphere } \\
\text { D.E. Rate } \\
\text { mrem/hr }\end{array}$ & $\begin{array}{l}\text { TEPC } \\
\text { D.E. Rate } \\
\text { mrem/hr }\end{array}$ & $\begin{array}{l}\text { Cyl. } \\
\text { D.E. Rate } \\
\mathrm{mrem} / \mathrm{hr} \\
\end{array}$ & $\begin{array}{l}\text { Spher. } \\
\text { D.E. Rate } \\
\text { mrem/hr }\end{array}$ & $\begin{array}{l}\text { TEPC } \\
\text { D.E. Rate } \\
\text { mrem/hr }\end{array}$ & $\begin{array}{l}\text { Cyl. } \\
\text { D.E. Rate } \\
\text { mrem/hr }\end{array}$ & $\begin{array}{l}\text { Spher. } \\
\text { D. E. Rate } \\
\mathrm{mrem} / \mathrm{hr}\end{array}$ \\
\hline E1 & 0.9 & --- & 0.85 & 1.4 & 1.0 & 1.2 & 1.6 \\
\hline E2 & 2.4 & -- & 1.9 & 2.8 & $\cdots$ & $\cdots$ & $\ldots$ \\
\hline E3 & 0.9 & $\cdots$ & 0.75 & 1.2 & 0.4 & 0.7 & 0.6 \\
\hline $\mathrm{F} 1$ & -- & 1.2 & 3.0 & 4.8 & $\ldots$ & -- & $\cdots$ \\
\hline F5 & 5.0 & $\cdots$ & 6.5 & 6.5 & $\cdots$ & $\cdots$ & -- \\
\hline F10 & 2.4 & 3.6 & 8.0 & 8.0 & --- & $\cdots$ &.- \\
\hline F11 & 0.9 & 1.7 & 3.0 & 4.0 & -- & $\cdots$ & --- \\
\hline 941 & $-\cdots$ & 0.3 &.-- & $\ldots$ & -- & -.- & -- \\
\hline G2 & 16 & 11 & 12 & 14 & $2.7(a)$ & 13 & 8 \\
\hline mases & 19 & --- & 20 & 24 & $7.0(a)$ & 15 & 13 \\
\hline C9 & 98 & --- & --- & 140 & $40^{(a)}$ & 100 & 75 \\
\hline G15 & --- & $\cdots$ & 150 & 175 & $65^{\text {(a) }}$ & 120 & 100 \\
\hline $\mathrm{CA}$ & -- & 851 &.- & 500 & $\cdots$ &.- & -- \\
\hline $\mathrm{H} 2$ & $\cdots$ & 6,000 & $\cdots$ & 30,000 & $\cdots$ & $\cdots$ & -- \\
\hline $\mathrm{H} 3$ & $\cdots$ & 200 & 475 & -.. & $\cdots$ & --- & -- \\
\hline $\mathrm{H}_{4}$ & -- & 185 & 1,200 & -- & --- & $\ldots$ & $\ldots$ \\
\hline H5 &.- & 495 & -.- & 2,000 &.- & --- & -- \\
\hline $\mathrm{H} 12$ & 32 & $\cdots$ & -- & -. & -- & $\cdots$ & $\cdots$ \\
\hline $\mathrm{H} 14$ & 30 & --- & -- & -- & --- & -- & -- \\
\hline \multicolumn{8}{|l|}{ First Visit } \\
\hline 11 & 45 & 41 & 80 & 120 & -- & $\cdots$ & -- \\
\hline 12 & 24 & $\cdots$ & 30 & 60 & -- & $\cdots$ & -- \\
\hline 13 & 8.6 & 10 & 20 & 20 & -- & -- & --- \\
\hline I Interlock & 1.5 & -- & -- & -.- &.- & $\cdots$ & $\cdots$ \\
\hline 14 & -- & 560 & 1,300 & 1,600 & -- & --- & --- \\
\hline 15 & --- & 290 & 650 & 960 & $\cdots$ & -- & $\cdots$ \\
\hline 112 & $\cdots$ & 3,080 & 4,510 & 4,540 & $\cdots$ & $\cdots$ &.-- \\
\hline \multicolumn{8}{|l|}{ Second Visit } \\
\hline 14 & 17 & 16 & 35 & 86 & 17 & 80 & 62 \\
\hline 17 & 3.5 & -- & 10 & 22 & 3.6 & $\cdots$ & $\cdots$ \\
\hline 18 & 23 & 29 & 52 & 118 & 26 & 130 & 97 \\
\hline 110 & $\cdots$ & --- & 160 & $\cdots$ & 180 & 1,300 & 930 \\
\hline $112 \mathrm{~A}$ &.- & 100 & $\cdots$ & $-\cdot$ & 78 & 360 & 240 \\
\hline 113 & $\cdots$ & 0.05 & $\cdots$ & $\cdots$ & -- & $\cdots$ & $\cdots$ \\
\hline J3 & 7.6 & --- & 12 & -- & $\cdots$ & $\cdots$ & $\cdots$ \\
\hline
\end{tabular}

(a) After retrofit installation of bioshields. 


\subsection{CONCLUSIONS}

Albedo dosimeter results were corrected, using 9-in. to 3-in. remmeter ratios, to agree (to within an average of $50 \%$ ) with dose equivalents measured either with multispheres containing large ${ }^{6} \mathrm{Li}(\mathrm{Eu})$ detectors or with TEPCs. For the purpose of this report dose equivalent measurements made with multispheres containing large $\mathrm{Li}(\mathrm{Eu})$ detectors are considered "reference" dose equivalents. Closer percentage agreement is seen between corrected albedo dosimeter results and spherical remmeter dose equivalents. However, the lack of agreement between the remmeter dose equivalents and the reference dose equivalents must also be taken in to account.

In Table 1, the cylindrical and spherical remmeters used by PNL had average overresponse factors of 1.7 and 2.9 , respectively. However, in Table 3 , the apparent overresponse factors were 4.2 for the cylindrical remmeter and 3.3 for the spherical remmeter. In the latter case, the remmeters were compared not to the reference dose equivalent, but to an alternate dose equivalent derived from tissue equivalent proportional counters. The obvious differences in the remmeter-reference ratios compared to the remmeter-TEPC ratios may be due, in most cases, to changes in the neutron spectra at the various power reactors between visits. However, there is sufficient contradictory data to preclude equating the reference dose equivalent (Table 1) to the TEPC dose equivalent (Table 3) for the purposes of this report.

The results of the EML remmeter-reference and remmeter alternate ratios are found in Tables 2 and 4. In Table 2, we might expect to see ratios similar to those of Table 1 , because identical reference systems were used. However, the cylindrical remmeter-reference ratios in Table 2 except for one are close to unity or about one-half the value of the average Table 1 value. Most of the Table 2 spherical remmeter-reference ratios are also lower than their Table 1 counterparts. However, two of the Table 2 ratios are much higher. Table 4 has one site with high remmeter-alternate ratios and one site where these ratios are low. Because the nonagreement in the remmeter-reference/ alternate ratios is not significantly reflected in 9 -in. to $3-i n$. or $10-i n$. to $3-i n$. ratio variations, it is probable that the remmeters were not calibrated to equal neutron fields or that the remmeters malfunctioned in some cases. It is not possible, with the data presented in Tables 2 and 4 , to determine whether the reference multispheres yield dose equivalents of similar magnitude as the alternate multispheres. However, direct comparisons at the same locations seem to indicate a lack of agreement for the different multisphere detectors (see Table 7). The degree to which a difference of a few feet in the placement of the multispheres changed the neutron dose equivalent is unknown, but may be large. 
The remmeter-reference dose equivalent ratios can be plotted against the 9 -in. to $3-i n$. ratios in the same manner as the albedo dosimeter response factors are related to the 9 -in. to 3 -in. ratios. This allows one to correct for the variation in the response of the remmeters with energy. The plot for Table $19-i n$. to 3 -in. ratio versus remmeter-reference ratio is shown in Figure 5. It is reminiscent of Figures 1 and 3.

The ratios of the $9-i n$. remmeter readings to the $3-i n$, remmeter readings did not show the wide variation, in any of the first four tables, that was typical of the other parameters. The ratios of the results for 10-in. and 3-in. multisphere balls were similar to the $9-i n$. to $3-i n$. ratios with the average 10-in. to $3-i n$. ratio about 1.5 times as large as the 9 -in. to 3 -in. ratio. The $9-i n$. to $3-i n$. (or $10-i n$. to $3-i n$.) ratio can be used to find correction factors for the albedo dosimeter and the remmeter. Both the 9-in. to 3-in. (10-in. to $3-i n$. ) ratios at the one BWR visited by PNL were significantly greater than 9-in. to $3-i n$. ratios for PWRs.

Neutron gamma ratios are only useful primarily as an approximate method of checking whether a combined neutron-gamma radiation field in a reactor has changed.

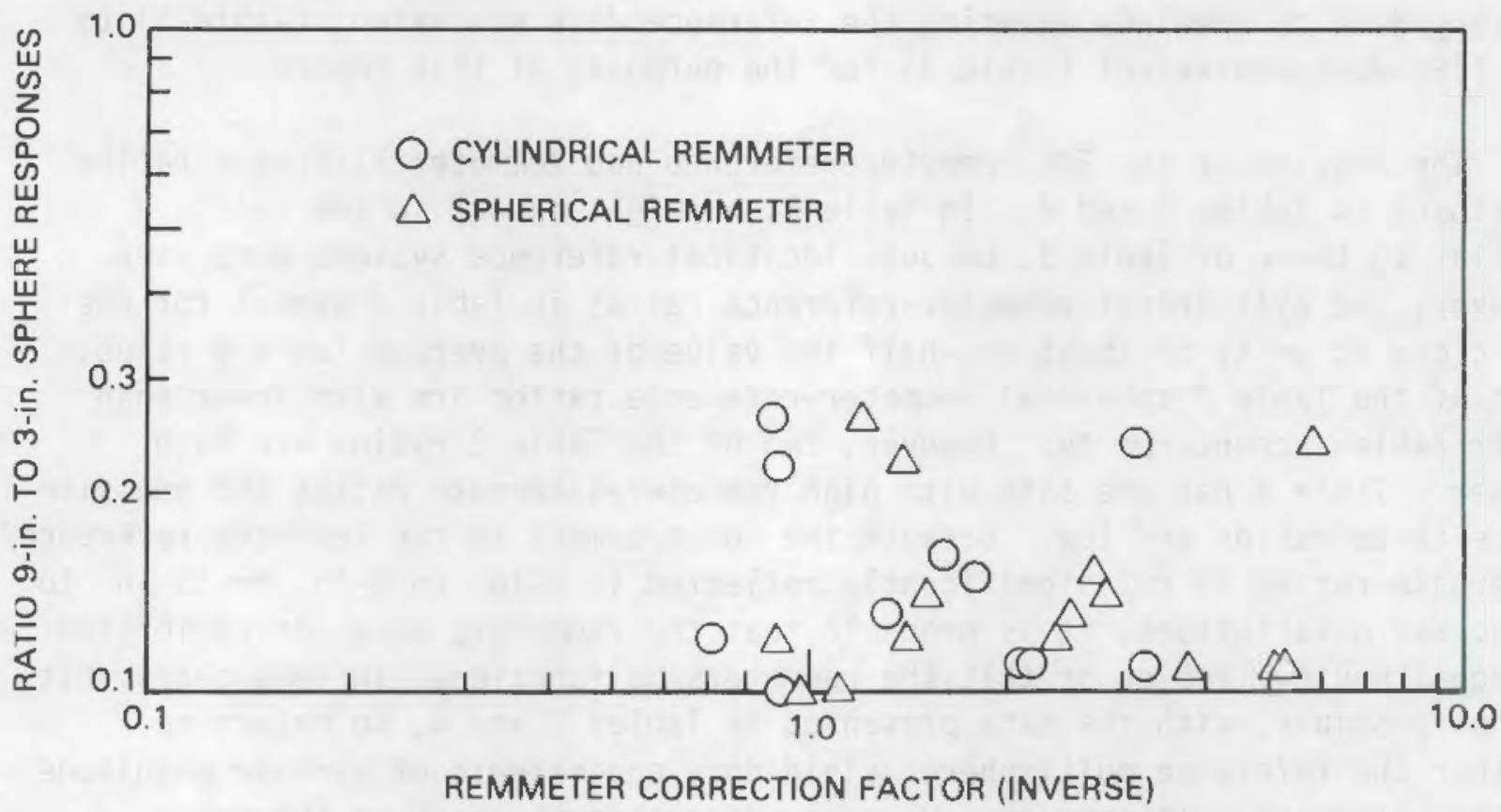

FIGURE 5. Measured Remmeter Correction Factors (Inverse) Plotted Against Measured 9-in. to $3-i n$. Sphere Response Ratios 
TABLE 7. Comparisons of Different Detectors in Multisphere Systems (EML Data)

\begin{tabular}{|c|c|c|c|}
\hline Site & Location & Detector & $\begin{array}{l}\quad \text { Dose } \\
\text { Equivalent } \\
\text { (mrem/hr) } \\
\end{array}$ \\
\hline NPS-2 & 1 & $\begin{array}{l}\text { Large }{ }^{6} \mathrm{LiI} \text { (Eu) } \\
\text { Sma11 }{ }_{\mathrm{Li}} \text { I(Eu) } \\
\text { Rensselaer TLD }\end{array}$ & $\begin{array}{c}11.3 \\
6.56 \\
10.3\end{array}$ \\
\hline NPS -3 & 1 & $\begin{array}{l}\text { Large }{ }^{6} \mathrm{LiI}(\mathrm{Eu}) \\
\text { Smail }{ }^{6} \mathrm{LiI}(\mathrm{Eu}) \\
\text { EML TLD }\end{array}$ & $\begin{array}{l}5.84 \\
4.22 \\
4.16\end{array}$ \\
\hline NPS-3 & 2 & $\begin{array}{l}\text { Large }{ }^{6} \mathrm{Li} \text { I (Eu) } \\
\text { Sma11 }{ }_{\text {Li I (Eu) }} \\
\text { Rensselaer TLD }\end{array}$ & $\begin{array}{l}31.2 \\
23.9 \\
8.95\end{array}$ \\
\hline NPS - 4 & 1 & $\begin{array}{l}\text { Large }{ }^{6} \mathrm{LiI}(\mathrm{Eu}) \\
\text { Sma11 }{ }^{6} \mathrm{LiI}(\mathrm{Eu}) \\
\text { EML TLD }\end{array}$ & $\begin{array}{l}7.39 \\
3.85 \\
15.0\end{array}$ \\
\hline NPS -4 & 2 & $\begin{array}{ll}\text { Large } & 6 \\
\text { Smail } & { }^{\mathrm{Li}} \mathrm{Li}(\mathrm{Eu}) \\
\mathrm{Li}(\mathrm{Eu})\end{array}$ & $\begin{array}{c}10.0 \\
5.06\end{array}$ \\
\hline NPS - 4 & 3 & $\begin{array}{ll}\text { Large } & 6 \\
\text { Sma } 11 & { }^{2} \mathrm{Li}(\mathrm{Eu}) \\
\mathrm{Li}(\mathrm{Eu})\end{array}$ & $\begin{array}{l}8.44 \\
7.11\end{array}$ \\
\hline NPS -6 & 1 & $\begin{array}{l}\text { EML TLD } \\
\text { EML TLD }\end{array}$ & $\begin{array}{c}11.4 \\
9.99\end{array}$ \\
\hline NPS -6 & 3 & $\begin{array}{l}\text { EML TLD } \\
\text { Rensselaer TLD }\end{array}$ & $\begin{array}{l}69.0 \\
10.8\end{array}$ \\
\hline NPS -6 & 7 & $\begin{array}{ll}\text { Large } & { }^{6} \mathrm{LiI}(\mathrm{Eu}) \\
\text { SmaI1 } & { }^{\mathrm{Li}} \mathrm{Li}(\mathrm{Eu})\end{array}$ & $\begin{array}{l}0.10 \\
\text { D. } 09\end{array}$ \\
\hline NPS -6 & 8 & $\begin{array}{ll}\text { Large } & 6 \mathrm{LiI}(\mathrm{Eu}) \\
\text { Small } & 6 \mathrm{LiI}(\mathrm{Eu})\end{array}$ & $\begin{array}{l}0.15 \\
\text { D. } 08\end{array}$ \\
\hline NPS-7 & 3 & $\begin{array}{ll}\text { Large } & 6 \\
\text { Sma } 11 & 6 i I(E u) \\
L i I(E u)\end{array}$ & $\begin{array}{l}29.5 \\
19.7\end{array}$ \\
\hline NPS -7 & 4 & $\begin{array}{ll}\text { Large } & { }^{6} \mathrm{LiI}(\mathrm{Eu}) \\
\text { Sma11 } & { }^{6} \mathrm{LiI}(\mathrm{Eu})\end{array}$ & $\begin{array}{c}12.2 \\
8.34\end{array}$ \\
\hline
\end{tabular}




\subsection{RECOMMENDATIONS}

At this time, the most practical method of determining dose equivalents to personnel at commercial nuclear power plants is through the use of albedo dosimeters. The response of these dosimeters must be corrected for energy dependence. This should be accomplished with the aid of a correction factor relating the dosimeter response at each location of interest in a power reactor to the best estimate of the true dose equivalent at that location.

The true dose equivalent can be closely approximated using TEPCs or multispheres. It is recommended this be done at least once at each operating reactor. Remmeters should continue to be used for obtaining 9-in. to 3-in. ratios and for routine monitoring. Because remmeters do not have a linear energy response, it is important that they be calibrated against a neutron source whose energy approximates that found in the power reactor area where the remmeters are to be used. Calibration with a bare $\mathrm{Cf}-252$ source will cause the remmeters to respond high by a factor of approximately 2 . If the 9 -in. to $3-i n$. ratio is greater than 0.20 , a best fit 1 ine through the points plotted in Figure 2 or 4 should be used to find a correction factor. If the 9 -in. to $3-i n$. ratio is 0.20 or less, an average correction factor should be used.

The measurement of gamma radiation levels in a mixed neutron-gamma field may be useful to find gross changes in the neutron dose-equivalent. However, the neutron-gamma ratio is not a reliable indicator of albedo dosimeter response and is not recommended for use at nuclear power plants.

In many instances a lack of data for comparisons made definitive judgments about relationships of the various parameters in this study difficult if not impossible. It is important to determine whether TEPC and multisphere measurements yield similar results. More BWR data is needed. More 9-in. to 3 -in. ratios should be obtained with well calibrated remmeters. Albedo dosimeters should be placed on phantoms at the same locations where remmeter and multisphere measurements were obtained for comparison purposes. 


\subsection{REFERENCES}

Curmings, F. M., G. W. R. Endres and L. W. Brackenbush. 1983. Neutron Dosimetry at Commercial Nuclear Plants. Final Report of Subtask B: Dosimeter Response. NUREG/CR-2956 (PNL-4471), Pacific Northwest Laboratory, Richland, Washington.

Endres, G. W. R., J. M. Aldrich, L. W. Brackenbush, L. G. Faust, and R. V. Griffith and D. E. Hankins. 1981. Neutron Dosimetry at Commercial Nuclear Plants. Final Report of Subtask A: Reactor Containment Measurements. NUREG/CR-1769 (PNL-3585), Pacific Northwest Laboratory, Richland, Washington.

Griffith, R. V., D. E. Hankins, R. B. Gammage, L. Tommasino and R. V. Sheeler. 1979. "Recent Developments in Personnel Neutron Dosimeters - A Review." Health Phys. 36:235-260.

Ryan, R. M. 1983. Evaluation of Personnel Neutron Dosimetry. NUREG/CR-2524, Rensselaer Polytechnic Institute, Troy, New York.

Sanna, R. S., F. Hajnal, J. E. McLaughl in, J. F. Gulbin and R. M. Ryan. 1980. Neutron Measurements Inside PWR Containments. EML-379, Environmental Measurements Laboratory, Washington, D.C.

Schwartz, R. B., G. W. R. Endres and F. M. Cummings. 1982. Neutron Dosimetry Performance and Associated Calibrations at Nuclear Power Plants. NUREG/CR2233, National Bureau of Standards, Gaithersburg, Maryland and Pacific Northwest Laboratory, Richland, Washington. 



\section{DISTRIBUTION}

No. of

Copies

OFFSITE

U.S. Nuclear Regulatory Commission

Division of Technical Information and Document Control

7920 Norfold Avenue

Bethesda, MD 20014

20 Margaret Federline

U.S. Nuclear Regulatory Commission

Office of Radiation Protection

NL-5650

Rockville, MD 20852

2 N. A. Dennis

U.S. Nuclear Regulatory Commission

Region 1

631 Park Avenue

King of Prussia, PA 19406

2 F. M. Costello

U.S. Nuclear Regulatory Cormission

Region 1

631 Park Avenue

King of Prussia, PA 19406

2 R. B. Schwartz

U.S. National Bureau of Standards

Quince Orchard Road

Gaithersburg, MD 20760

2 A. Zirkes

Dosimeter Corporation

P.0. Box 42377

Cincinnati, $\mathrm{OH} 45242$
No. of

Copies

2 R. V. Wheeler

R. S. Landauer, Jr. and Co.

Glenwood Science Park

Glenwood, IL 60425

2 C. Distenfeld

Teledyne Isotopes

50 Van Buren Avenue

Westwood, NJ 07675

2 R. Geiger

Eberl ine Company

P.0. Box 2108

Santa Fe, NM 87501

2 Richard Griffith

Hazards Control Department

Lawrence Livermore National Laboratory

P.0. Box 5505

Livermore, CA 94550

ONSITE

26 Pacific Northwest Laboratory

L. W. Brackenbush

F. M. Cummings

G. W. R. Endres

T. H. Essig

L. G. Faust

D. L. Haggard

J. J. Jech

L. A. Rathbun (10)

R. I. Scherpelz

K. L. Soldat

Technical Information (5)

Publishing Coordination (2) 


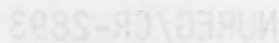

$2058-1129$

(n)

1017406191210

$70=0$

$29+1009$

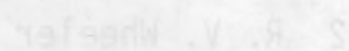

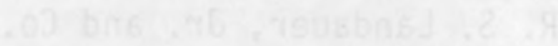

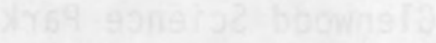

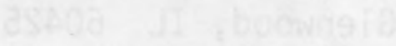

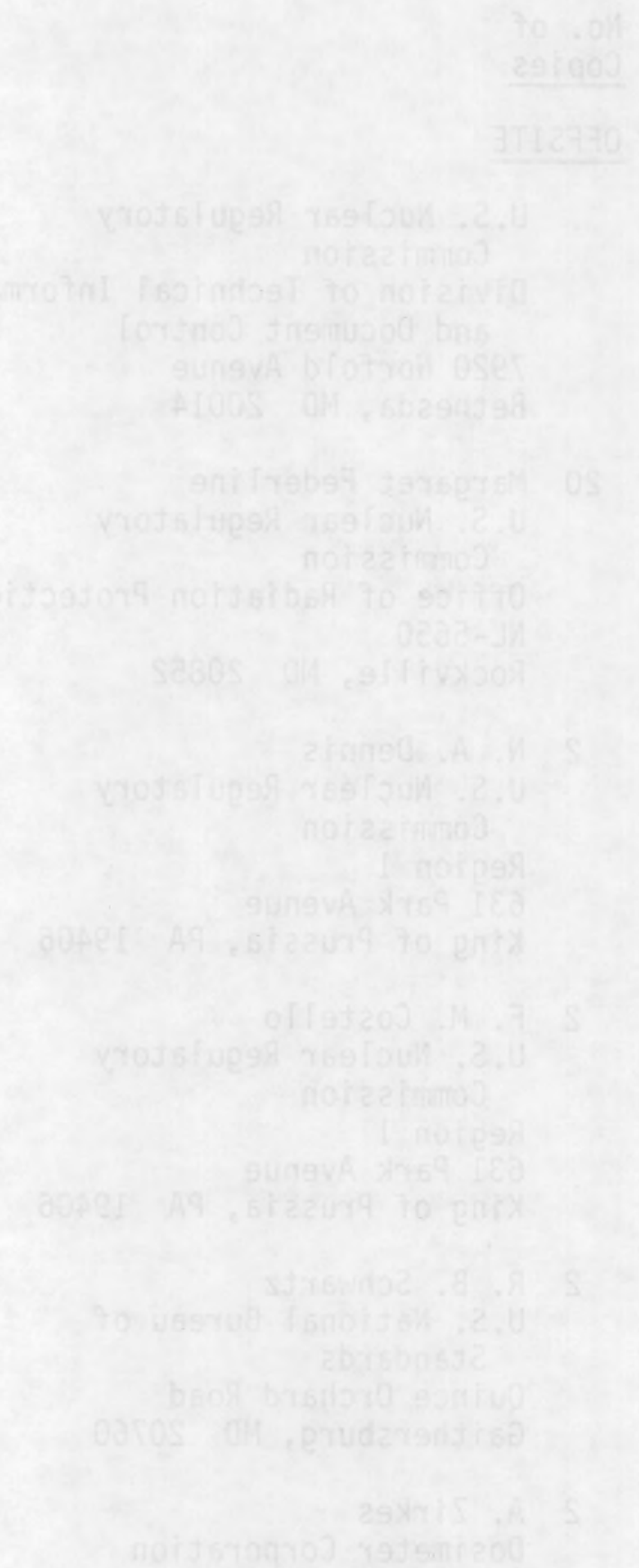

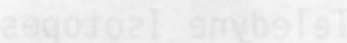

Wh9

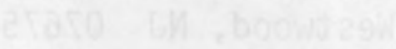

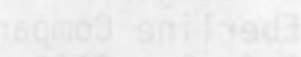

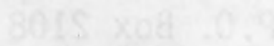

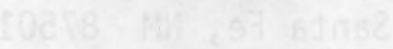

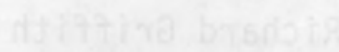

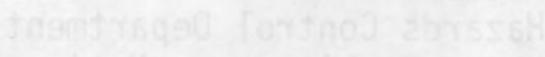

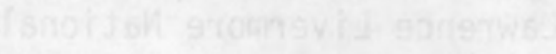

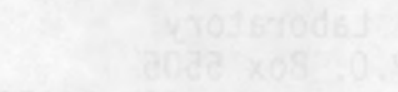

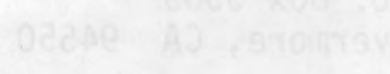

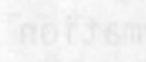

bris

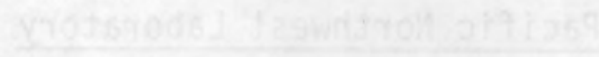

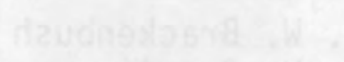$$
\text { 20975 anas }
$$

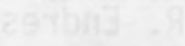$$
\text { piraz }
$$

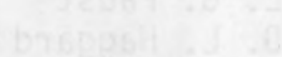$$
\text { 0i) }
$$$$
\text { 38 }
$$$$
356502+2.3
$$

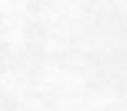

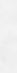




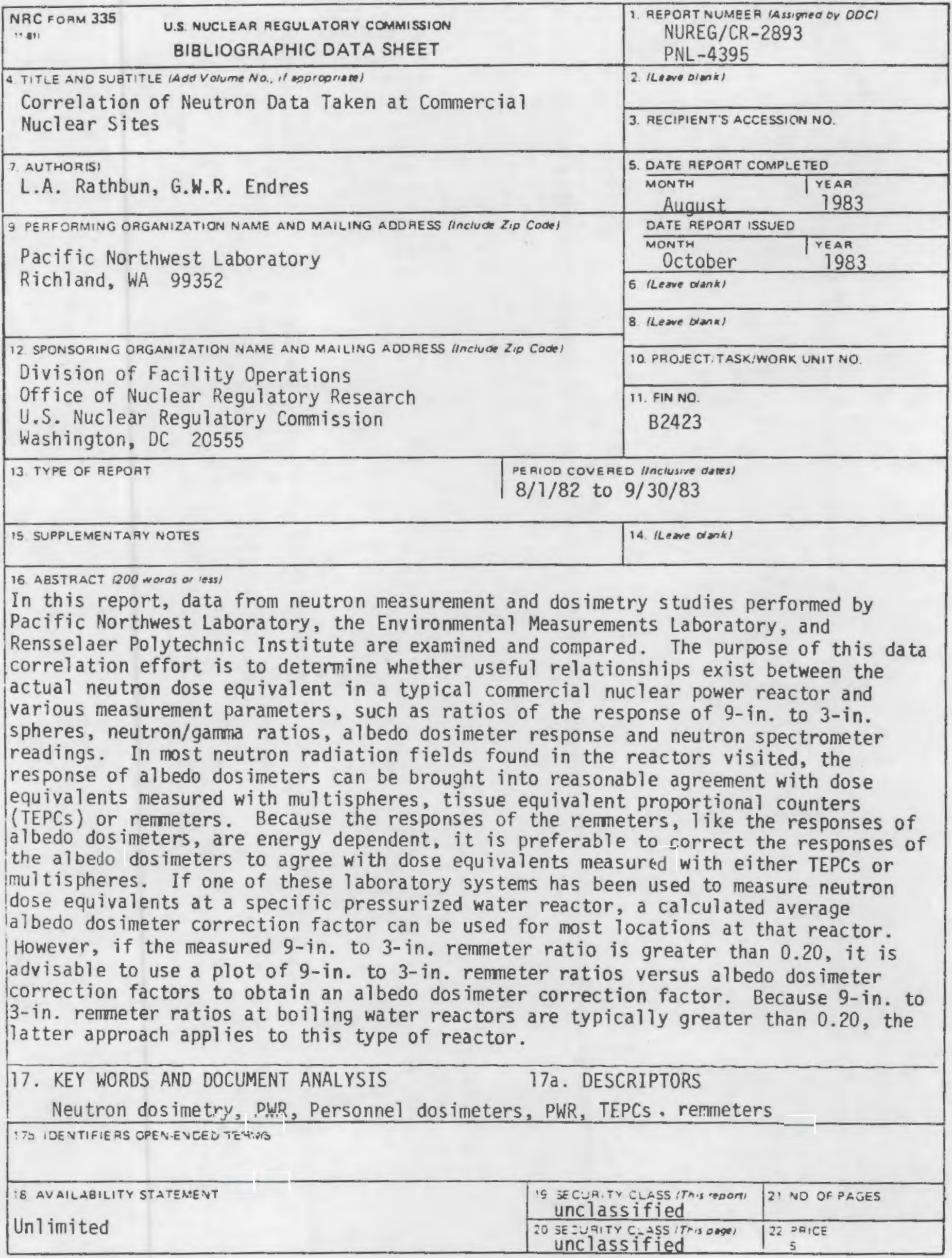




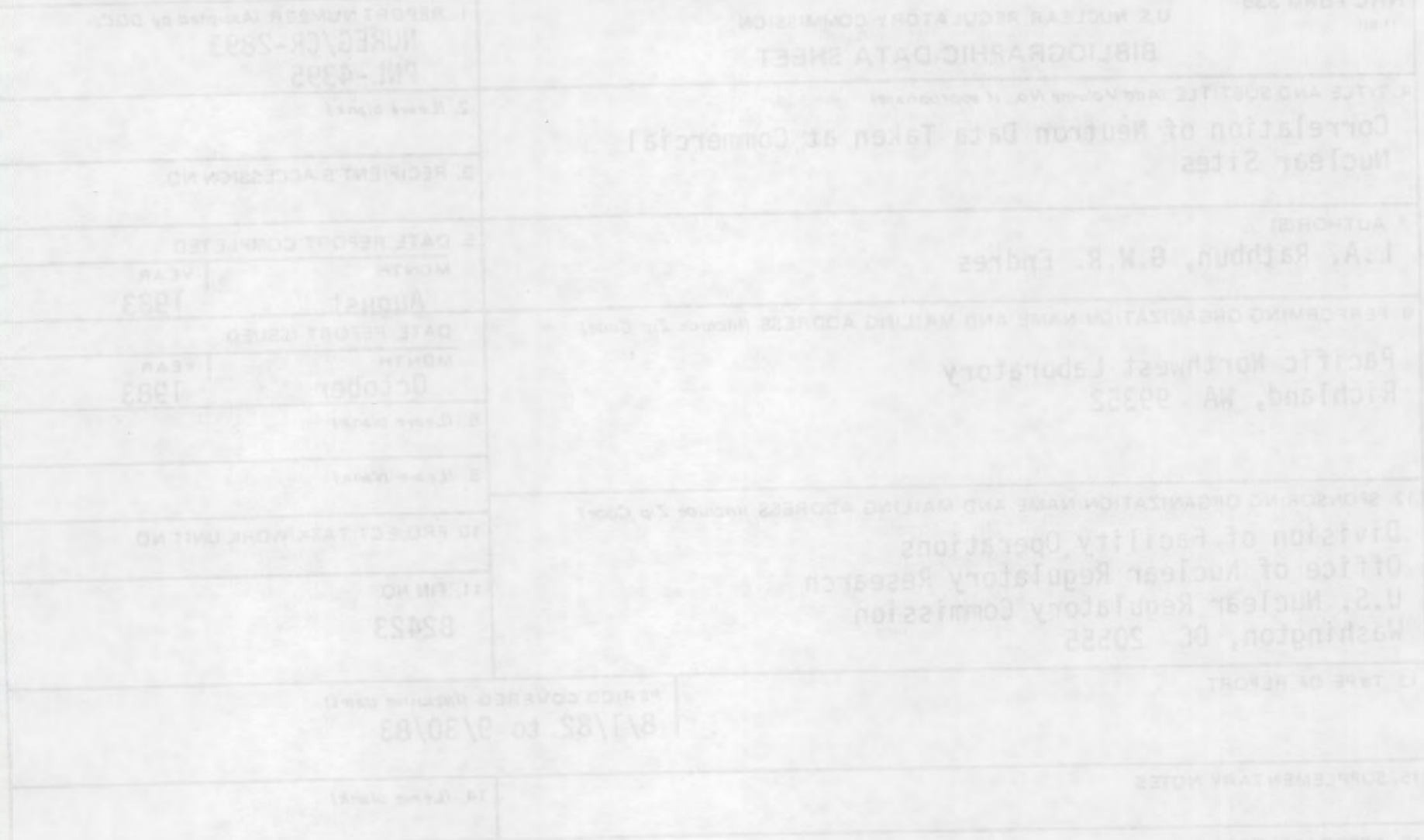

bat st

20107019

2099

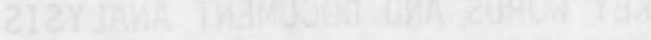

5. 